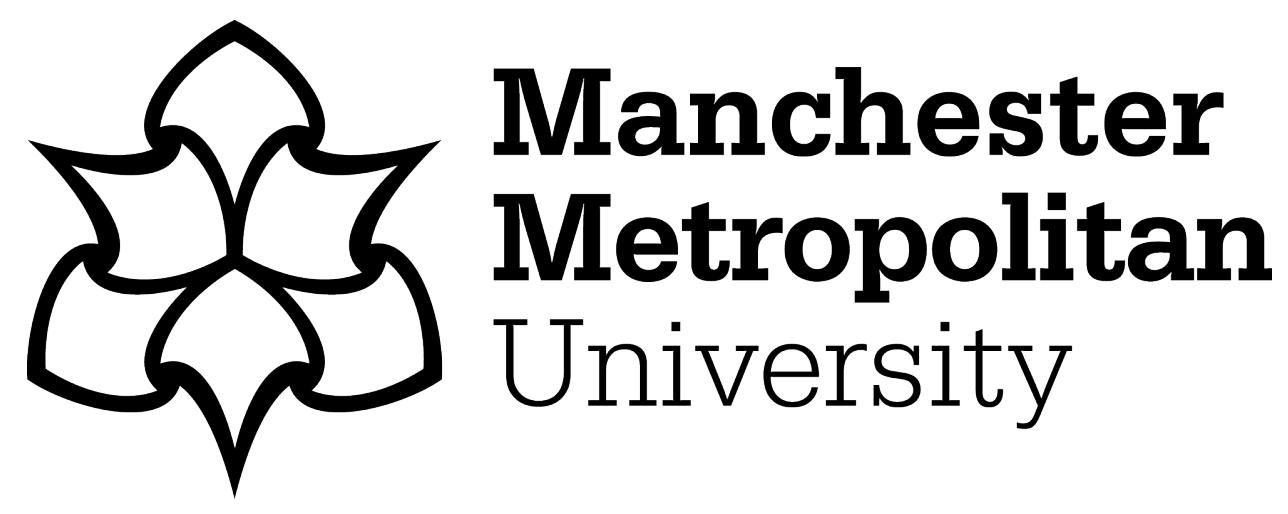

Fan, $\mathrm{Y}$ and Stevenson, M (2018) Reading on and between the lines: risk identification in collaborative and adversarial buyer-supplier relationships. Supply Chain Management: An International Journal, 23 (4). pp. 351-376. ISSN 1359-8546

Downloaded from: https://e-space.mmu.ac.uk/621433/

Version: Accepted Version

Publisher: Emerald

DOI: https://doi.org/10.1108/SCM-04-2017-0144

Please cite the published version 


\section{Reading on and between the lines: \\ Risk identification in collaborative and adversarial buyer- supplier relationships}

\begin{tabular}{|r|l|}
\hline Journal: & Supply Chain Management: an International Journal \\
\hline Manuscript ID & SCM-04-2017-0144.R3 \\
\hline Manuscript Type: & Original Manuscript \\
\hline Keywords: & $\begin{array}{l}\text { Risk Management, Social Capital, Supplier-manufacturer relationships, } \\
\text { Case Studies, Supply risk }\end{array}$ \\
\hline \multicolumn{2}{|l}{} \\
\hline
\end{tabular}

\section{SCHOLARONE ${ }^{\text {th }}$ \\ Manuscripts}




\title{
Reading On and Between the Lines:
}

\section{Risk Identification in Collaborative and Adversarial Buyer-Supplier Relationships}

\begin{abstract}
Purpose: To investigate how supply chain risks can be identified in both collaborative and adversarial buyer-supplier relationships (BSRs).

Design/methodology/approach: A multiple case study involving ten Chinese manufacturers with two informants per organisation. Data has been interpreted from a multi-level social capital perspective (i.e. from both an individual and organisational level), supplemented by signalling theory.

Findings: Buyers employ different risk identification strategies or apply the same strategy in different ways according to the BSR type. The impact of organisational social capital on risk identification is contingent upon the degree to which individual social capital is deployed in a way that benefits the individual's own agenda versus that of the organisation. Signalling theory generally complements social capital theory and helps further understand how buyers can identify risks, especially in adversarial BSRs, e.g. by using indirect signals from suppliers or other supply chain actors to 'read between the lines' and anticipate risks.
\end{abstract}

Research limitations/implications: Data collection is focused on China and is from the buyer side only. Future research could explore other contexts and include the supplier perspective.

Practical implications: The types of relationships that are developed by buyers with their supply chain partners at an organisational and an individual level have implications for risk exposure and how risks can be identified. The multi-level analysis highlights how strategies such as employee rotation and retention can be deployed to support risk identification.

Originality/value: Much of the extant literature on supply chain risk management is focused on risk mitigation whereas risk identification is under-represented. A unique case-based insight is provided into risk identification in different types of BSRs using a multi-level social capital approach complemented by signalling theory.

Keywords: Supply chain risk; Risk identification; Buyer-supplier relationship; Organisational social capital; Individual social capital; Signalling theory.

Paper type: Research paper 


\section{Introduction}

Supply chain risk management (SCRM) is aimed at developing strategies for the identification, assessment, mitigation, and monitoring of supply chain risks (SCRs) (e.g. Tummala and Schoenherr, 2011). SCR can be understood as the probability of an incident associated with a supply chain from, e.g. individual supplier failures, leading to operational, tactical, or strategic level failures or irregularities (Zsidisin, 2003; Ho et al., 2015). The importance and challenge of dealing with SCRs makes SCRM a key topic. Risk identification is a crucial first stage of SCRM (Neiger et al., 2009; Kern et al., 2012). If this stage is mismanaged, it can undermine the rest of the SCRM process (Kern et al., 2012). Thus, it is important that organisations find effective ways of quickly and accurately identifying risks; and the importance of this has been acknowledged by leading manufacturers such as Dell, Toyota, and Motorola (Chopra and Sodhi, 2004). Many sophisticated approaches have been presented for identifying risks, e.g. the value-focused process engineering (VFPE) methodology (Neiger et al., 2009) and the knowledge-based supply chain risk identification system (SCRIS) (Kayis and Karningsih, 2012). But developing and implementing these methods is costly and time-consuming (Chen et al., 2016), and SCRM budgets and resources are often limited. Therefore, firms often seek other ways of effectively identifying risks.

It has been argued that building collaborative supply chain relationships, referring to "two or more autonomous firms working jointly to plan and execute supply chain operations" (Cao and Zhang, 2011, p. 163), can aid risk identification (Scholten and Schilder, 2015; Chen et al., 2016). Such relationships can help to share information about risks and identify risks sooner, potentially before they affect the supply chain. Yet although prior research has examined how collaborative buyer-supplier relationships (BSRs) can facilitate SCRM in general (e.g. Lavastre et al., 2014), aid in (Li et al., 2015) or potentially hinder (e.g. Nishiguchi and Beaudet, 1998; Villena et al., 2011) risk mitigation, their influence on risk identification remains empirically unexplored. Moreover, not all BSRs will be collaborative - and there may be good reasons why a more adversarial relationship exists - but the ability to identify risks remains important. The literature currently offers no insight into how to effectively identify SCRs in non-collaborative BSRs.

Much of the limited prior empirical work on risk identification has been conducted in a developed country context, e.g. the UK (e.g. Roehrich et al., 2014) or USA (e.g. Lockamy 
and McCormack, 2010). There is a need to extend this work to developing countries such as China, which is an important Eastern destination for manufacturing where guanxi, which has been referred to as both a social practice for building and using interpersonal relationships (e.g. Chen et al., 2004; Chen et al., 2013) and as a strategy for firms to gain competitive advantage (e.g. Peng and Luo, 2000; Gu et al., 2008; Opper et al., 2017), plays a critical role in business and SCRM activities (Jia and Zsidisin, 2014). Expanding research in this direction may complement the extant literature on risk identification and provide new insights for practice.

In this paper, we present empirical evidence from ten manufacturing firms in China, examining how buyers identify risks in different types of BSRs. The dyadic BSR represents the smallest unit of analysis for studying important supply chain phenomena. We seek to address the following research question:

\section{How does the nature of the buyer-supplier relationship affect supply chain} risk identification?

Our analysis is aided first by social capital theory and second by signalling theory. Social capital theory is our primary, a-priori theoretical lens. It can be defined as "the sum of the actual and potential resources embedded within, available through, and derived from the network of relationships possessed by an individual or social unit" (Nahapiet and Ghoshal, 1998, p. 243). This definition acknowledges that social capital may reside at both an individual and an organisational level. Indeed, inter-firm relationships almost always depend on individuals connecting people affiliated with other firms. The owners of organisations therefore do not always control these connections and consequently cannot always profit from them (Sorenson and Rogan, 2014). Thus, it is necessary to consider social capital at both an individual and an organisational level to understand how BSRs influence risk identification. The context (i.e. China) chosen for this study also necessitates the application of social capital from a multi-level theoretical perspective. Guanxi, which is closely related to individual social capital, is cultivated by managers in their personal relationships (Park and Luo, 2001). This is in contrast to organisational-level social capital, which is often not easily transferable or traded (Nahapiet and Ghoshal, 1998). Yet, there are also negative aspects of guanxi (Gu et al., 2008) that relate to the dark-side of social capital in BSRs (Villena et al., 2011). The prior supply chain management (SCM) literature however has focused on a single level of social capital analysis - using data to capture and measure the construct at the 
organisation level only.

Although social capital theory is of high utility for understanding collaborative BSRs, we find that it does not adequately enhance our understanding of how risks can be identified in adversarial BSRs. We therefore supplement social capital theory with signalling theory (Spence, 1973), which helps us to understand how buyers can overcome the information asymmetry that often exists in an adversarial BSR to identify potential risks that the supplier may not otherwise disclose to the buyer.

The remainder of this paper is organised as follows. Section 2 reviews literature relating to risk identification and BSRs before explaining our rationale for using social capital theory, demonstrating its fit with SCR research and outlining why it is necessary to apply it at both an organisational and individual level. Section 3 discusses the research method adopted before an overview of SCRs and risk identification strategies is presented in Section 4 together with an analysis of the case study evidence from a multi-level social capital perspective. Signalling theory is then used to complement social capital theory in Section 5 before we discuss our overall findings and present five propositions in Section 6. The paper concludes in Section 7, where we highlight key theoretical and managerial implications.

\section{Literature Review}

\subsection{SCR Identification}

Risk identification aims to discover all relevant risks (Kern et al., 2012); to reveal different risk types; and, to develop an understanding of the events and conditions driving risks (Narasimhan and Talluri, 2009). Kern et al. (2012) demonstrated that a company's risk identification endeavours can augment the level of risk analysis, which in turn enhances risk mitigation. This implies that an early judgement in risk identification is needed to determine whether a risk is relevant and thus should be further assessed (Faisal et al., 2006) and/or mitigated (Enyinda et al., 2010).

Much of the literature on SCR identification has sought to: (i) identify drivers (e.g. Peck, 2005; Roehrich et al., 2014), sources (e.g. Ritchie and Brindley, 2007), and consequences of SCRs (e.g. Ceryno et al., 2015); (ii) classify SCRs (e.g. Rangel et al., 2015); or (iii) propose risk identification strategies/approaches (e.g. Neiger et al., 2009). Researchers have also applied these risk identification strategies in specific industries, such as automotive (e.g. Xie et al., 2009) and pharmaceuticals (e.g. Kayis and Karningsih, 
2012; Elleuch et al., 2014), especially in a developed country context (e.g. Lockamy and McCormack, 2010; Roehrich et al., 2014). This line of work includes complex approaches, e.g. the analytical hierarchy process (AHP) (Gaudenzi and Borghesi, 2006), the value-focused process engineering (VFPE) methodology (Neiger et al., 2009), and the knowledge-based supply chain risk identification system (SCRIS) (Kayis and Karningsih, 2012); and the use of technology, e.g. label-card systems (Xie et al., 2009) and supply network decision support systems (Basole and Bellamy, 2014). Adopting these approaches however is time-consuming and resource-intensive, making them infeasible for many firms. Although simpler approaches exist, e.g. the Ishikawa diagram and value stream mapping (Lavastre et al., 2012), firms may need to find other cost-effective ways (Chopra and Sodhi, 2014) of identifying risks. One such approach is by building trusting relationships with suppliers, allowing information and knowledge about risks to be shared (Scholten and Schilder, 2015; Chen et al., 2016).

Building collaborative relationships with suppliers could aid risk identification (Badurdeen et al., 2014), but empirical evidence is needed to fully unpack how the nature of the BSR affects risk identification. Although it seems logical that buyer-supplier collaboration would be beneficial, it remains unclear how it aids risk identification and whether it always has a positive effect. For example, is it possible to be too collaborative? Moreover, given that not all BSRs will be collaborative, there is a need to understand how buyers can cost-effectively identify risks in non-collaborative relationships.

\subsection{BSRs and SCR Identification}

There are various typologies of BSRs in the literature, including those based on power-dependence (e.g. Cox, 2004), relational attributes (James and Faizul, 2000), and both relational and power-dependence (Tangpong et al., 2015). We follow the approach adopted in most prior studies on BSRs and SCRM, which is to focus on relational attributes, e.g. trust and collaboration (Li et al., 2015; Scholten and Schilder, 2015). Thus we use the prevailing bipolar BSR typology of collaborative-adversarial relationships (e.g. Carr and Pearson, 1999) where a collaborative relationship is characterised by closely-tied actors (Carr and Pearson, 1999) and an adversarial relationship by arm's-length actors (James and Faizul, 2000).

There is some literature that advocates developing collaborative BSRs to effectively identify SCRs (Khan et al., 2008; Badurdeen et al., 2014) and enhance warning 
capabilities (Riley et al., 2016). It has been suggested that various supplier performance indicators can be used to identify potential risks concerning, for example, inventory levels, production throughput, capacity utilisation, delivery lead times (Giannakis and Louis, 2011), infrastructure status, and financial stability (Schoenherr et al., 2008). Indeed, picking up on these cues or early-warning signs may help identify potential disruptive events before they occur (Blackhurst et al., 2008; Bode et al., 2014; Bühler et al., 2016) thereby improving the proactiveness and effectiveness of risk identification. There remains however limited empirical evidence; and, to the best of our knowledge, no prior studies have empirically investigated how to identify risks in both collaborative and adversarial BSRs.

\subsection{Theoretical Lens: Social Capital Theory and Its Relevance to Risk Identification}

Social capital theory, with its three dimensions of structural, relational, and cognitive capital (Nahapiet and Ghoshal, 1998), can be used to explore how networking relationships bring value to actors such as individuals or organisations (Leenders and Gabbay, 1999) by enabling them to access resources embedded in those relationships (Bourdieu and Wacquant, 1992) and by facilitating actions (Adler and Kwon, 2002). For example, Toyota develops social capital by creating and fostering social relations between personnel from within Toyota and from its suppliers to improve performance (Liker and Choi, 2004). It is therefore the theory frame adopted in this study. Social capital theory has recently been used to view BSRs in SCR research in order to: (i) explain the relationship between buyer and supplier (Cheng et al., 2012); (ii) bridge from inter-organisational relationships to resilience (Johnson et al., 2013); and (iii) study the antecedents of opportunism (Hartmann and Herb, 2014). None of these studies however explored how social capital influences SCR identification.

Social capital theory has been increasingly adopted in SCM research during the past decade (Krause et al., 2007; Villena et al., 2011; Roden and Lawson, 2014), but the use of social capital as a multi-level construct is rather limited (Payne et al., 2011; Kwon and Adler, 2014). Prior studies have implicitly imported the individual-level mechanism for social capital to the organisational level by collecting data from individuals whilst treating the organisation as the unitary actor - with the same sets of motivations, cognitions and emotions as individuals, such as the ability to trust one another (Sorenson and Rogan, 2014). In other words, using the individual as the unit of observation but treating the organisation as the unit of analysis. Undoubtedly, such importation has 
contributed to an improved understanding of BSRs and performance outcomes. But the link between social capital and performance has been theorised in general terms only. There is a need to look closer at the precise nature of how social capital influences risk identification in a multi-level context.

Within a BSR, we use the term individual social capital to refer to an individual's personal connections with his/her counterpart in the partner organisation and the information, influence, and solidarity derived from these connections (see Figure 1). We note that social capital as represented by the three dimensions - structural, cognitive, and relational - resides at both the individual and organisational level.

\section{[Take in Figure 1]}

The following subsections specify the meaning of each social capital dimension for risk identification. It is however noted that there are also interactions between the dimensions (Li et al., 2014), e.g. social interaction (i.e. structural dimension) is viewed as a prerequisite for creating trust (i.e. relational capital), which promotes common interests and mutual understanding (i.e. cognitive capital). It should also be noted that the following uses a broad interpretation of social capital as prior SCM research has not tended to differentiate between organisational and individual level social capital.

\subsubsection{Structural Capital and SCR Identification}

Structural capital refers to the "properties of the social system and of the network of relations as a whole" (Nahapiet and Ghoshal, 1998, p. 244). Burt (2004) explained it deals with who you reach and how you reach them; and it encompasses the structural configuration, diversity, centrality, and boundary-spanning roles of network participants (Krause et al., 2007). In BSRs, practices of building structural capital may range from general sharing of codified information to sharing tacit knowledge (Krause et al., 2007; Li et al., 2014). It also incorporates supplier evaluations and supplier development activities, such as visits to suppliers' facilities and supplier training (Krause et al., 2007). A higher level of structural capital is therefore likely in collaborative BSRs than in adversarial BSRs. For example, information exchanges are expected to be more detailed, intricate, and proprietary when the relationship is collaborative (Krause et al., 2007; Lawson et al., 2008).

Information and knowledge sharing is generally seen as critical to identifying SCRs (Kleindorfer and Saad, 2005) and to enhancing early warning capabilities (Riley et al., 
2016). For example, sharing risk-related information can allow the buyer to identify possible threats before they become actual risk events (Li et al., 2015). Without information, or if suppliers hold back information (Li et al., 2015), buyers may hesitate to act on SCRs (Riley et al., 2016). But sharing information could also be a source of vulnerability (Sharma and Routroy, 2016). For example, a supplier may decide to use proprietary information against the buyer for their own gain. This suggests that one strategy for identifying risks (information sharing) could potentially induce other, new risks (e.g. information risk or intellectual property risk). Therefore, it is expected that different levels of structural capital in different BSRs will affect the outcomes of risk identification initiatives.

\subsubsection{Cognitive Capital and SCR Identification}

Cognitive capital refers to "those resources providing shared representations, interpretations, and systems of meaning among parties" (Nahapiet and Ghoshal, 1998, p. 244). Tsai and Ghoshal (1998) suggested that cognitive capital is embodied by shared visions and collective goals among partners. Thus, a higher level of cognitive capital is expected in collaborative than in adversarial BSRs. For example, collaborative BSRs are likely to develop shared norms and values (Moran, 2005) and have a common understanding of what constitutes improvement and how to accomplish it (Krause et al., 2007). In contrast, if goals and values are incongruent, buyer-supplier interactions could lead to misinterpretation and conflict (Inkpen and Tsang, 2005).

Cognitive capital could improve understanding of SCRM between buyer and supplier, which could reduce errors, conflicts, and confusions (Li et al., 2015), enabling SCRs to be identified sooner (Faisal et al., 2006). By developing a shared understanding of SCRM, firms can improve their learning capabilities (Braunscheidel and Suresh, 2009) and have a better understanding of the knowledge and information specific to SCRs that is available to share with partners (Cao and Zhang, 2011; Li et al., 2015). It has however been suggested that a groupthink mentality can emerge that produces forms of collective blindness (Villena et al., 2011). Actors become too homogenous in their thinking leaving the buyer less likely to critically evaluate risk-related information. Thus, there is the potential for too much cognitive capital, which could hinder proactive risk identification.

\subsubsection{Relational Capital and SCR Identification}

Relational capital refers to "the kind of personal relationships people have developed with each other through a history of interactions" (Nahapiet and Ghoshal, 1998, p. 244). 
This dimension often concerns the characteristics and qualities of individual relationships, and the identity that a particular individual has within a network (Inkpen and Tsang, 2005). Relational capital comprises trust, cooperation, buyer dependence, supplier dependence, expectations, and obligations (Nahapiet and Ghoshal, 1998; Krause et al., 2007). Thus there is the potential for major differences in relational capital between collaborative and adversarial BSRs (Krause et al., 2007). The high level of relational capital likely in collaborative BSRs can help reduce transaction costs (Ojala and Hallikas, 2006), enhance cooperation (Villena et al., 2011), and reduce opportunistic behaviour (Faisal et al., 2007; Hartmann and Herb, 2014) even if short-term incentives exist (Li et al., 2015). The lower level of relational capital likely in adversarial BSRs, where buyers have limited information concerning a supplier's behaviour, technology, and costs, may lead to the supplier taking advantage of their private knowledge (Camuffo et al., 2007).

A lack of trust is considered a major contributor to SCR (Faisal et al., 2006; Lavastre et al., 2012). Thus, a higher level of relational capital has been associated with lower perceived risk (Cheng et al., 2012; Mishra et al., 2016). Moreover, trust can be considered a predictor of risk-sharing behaviour between supply chain parties (Jüttner, 2005; Li et al., 2015), thereby simplifying the complex decision-making process (Chen et al., 2016) in risk identification (Barker et al., 2010). But trust is also a fragile asset and is subjected to numerous stresses in a business environment (Spekman and Davis, 2004). Moreover, there is the potential for heightened risk if the buyer becomes over-dependent on a supplier (Govindan and Chaudhuri, 2016) and the supplier abuses the buyers' trust. Few studies however have recognised this problem (Villena et al., 2011).

\subsection{Assessment of the Literature}

Most prior studies concerning the role of BSRs in SCRM have focused on how collaboration may enable or hinder risk mitigation in the context of developed countries. Further research is needed to investigate the role of BSRs in risk identification particularly in developing countries such as China, e.g. to understand the role of country-specific practices (e.g. guanxi) in risk identification. Moreover, not all BSRs will be collaborative - and there may be good reasons why a more adversarial relationship exists - but the ability to identify risks remains important. Empirical research is therefore required to examine how both collaborative and non-collaborative BSRs influence risk identification. Moreover, few prior studies on SCRM have made use of theory. Greater use of established theory frames would deepen understanding and add 
external validity. Although prior studies have examined the social capital-performance link in general terms, further research is needed to study social capital at both an individual and organisational level. In response, we adopt a multi-case study approach to explore the role of BSRs in shaping risk identification in China. We begin by using social capital theory as a multi-level theoretical lens and later supplement this with signalling theory to further our understanding.

\section{Research Method}

\subsection{Research Design}

The case study method (Meredith, 1998; Eisenhardt and Graebner, 2007) adopted in this study is appropriate given the nascent state of the literature on the phenomenon (Edmondson and McManus, 2007). A multiple case study approach is applied to help guard against observer bias, augment external validity (Voss et al., 2002; Yin, 2014), and support theory building (Barratt et al., 2011). Four key measures for establishing the validity and reliability of case research (McCutcheon and Meredith, 1993; Stuart et al., 2002; Yin, 2014) are summarised in Table I with a description of how each has been addressed. The remainder of this section outlines the case selection process, data collection procedure, and data analysis approach.

\section{[Take in Table I]}

\subsection{Case Selection}

A case is defined as the buyer firm. We are interested in their experiences of SCR identification and in their upstream relationships with suppliers. Case selection is guided by theoretical interests rather than statistical sampling logic (Eisenhardt, 1989; Stuart et al., 2002; Yin, 2014). Four criteria for selection were specified: (i) organisations should be based in China; (ii) access to multiple suitable interviewees must be available to aid triangulation; (iii) organisations should have a number of upstream suppliers; and (iv) firms should have experiences of identifying SCRs. In addition, the focus was on manufacturers, i.e. the focal firms in product supply chains making them a good starting point for theory development (Manuj and Mentzer, 2008).

We selected ten cases, as summarised in Table II, which meet the above criteria. This number of cases works well according to Eisenhardt (1989) and Barratt et al. (2011) and allowed us to reach theoretical saturation (Eisenhardt, 1989). 
[Take in Table II]

\subsection{Data Collection}

The main data collection method has been semi-structured interviews. This approach provides a relatively open format yet is still focused on specific issues, allowing the researcher to guide the interviewee through the areas to be discussed (Easterby-Smith, 1991; Saunders et al., 2016). Interviews were conducted via telephone or video telephony for logistical reasons where the latter still allows the non-verbal behaviour of participants to be observed. Interviews were audio-recorded (and video-recorded) contributing towards an accurate, unbiased record and allowing for direct quotations (Voss et al., 2002; Saunders et al., 2016).

The interview questions (see Appendix A), which were sent to participants in advance, covered two main themes. First, the major SCRs that manufacturers in China have encountered or anticipate and the risk identification strategies employed (Appendix A, Section 2). And second, the linkages between BSRs, SCR, and risk identification (Appendix A, Section 3). The interview protocol was piloted with two interviewees. This led, for example, to using a sample list of SCRs to aid interviewees. Secondary data, e.g. from corporate reports, was used to triangulate the interviewees while websites provided background knowledge prior to an interview.

\subsection{Data Analysis}

Interviews were conducted in Chinese and fully transcribed using the translation-back-translation method (Brislin, 1970). Data analysis followed a three-step process of data reduction, data display, and conclusions (Miles and Huberman, 1994) supported by the use of qualitative data analysis software NVivo, which facilitates the coding process and data management. We started by assigning codes to extracts that were truly relevant to the research question. The transcripts were read several times to increase familiarity with the data, reduce the data, and refine the codes. The relevant data were coded to create new or apply existing nodes by the first author; a second author was also involved in coding development to reduce subjective bias. First-order codes were descriptive and close to the SCRM literature, e.g. SCR types and risk identification strategies. Second-order analysis involved moving back-and-forth between the theory and data to reveal new constructs, including factors that support (enablers) and hinder (barriers) each dimension of social capital. The content of the nodes was continuously reviewed and discussed until final agreement was reached to ensure consistency. The data 
analysis process continued until it was saturated (Robson, 2011).

\section{Findings: A Multi-Level Social Capital Perspective}

Before interpreting the data using social capital theory, we first provide an overview of the SCRs and identification strategies, as shown in Table III. If one or more interviewee from a given firm identified a risk or strategy, it was considered relevant to that firm. The data contains 43 SCRs categorised into three broad types from Christopher and Peck (2004). More specifically, 4 SCRs are external to the supply chain; 28 are internal to the supply chain but external to the organisation, further broken down into supply-side risks (22), demand-side risks (4), and network-related risks (2); and 11 were internal to the organisation. The most frequently mentioned SCRs were quality, price, and logistics related. In addition, 16 risk identification strategies are included in the table. Most strategies were initiated and adopted by buyers, particularly supplier evaluations and auditing. But other parties, including suppliers, customers, and third-party organisations also play a role in identifying SCRs.

[Take in Table III]

Enablers and barriers to the three dimensions of social capital at both an organisational and individual level are summarised in Table IV, while example quotations are given in tables V to VII. Enablers of organisational level social capital support the formalisation and accumulation of organisational social capital and are particularly evident in collaborative BSRs while barriers to organisational social capital work against the formalisation and accumulation of organisational social capital and explain why organisational social capital is typically low in adversarial BSRs.

We differentiate between enablers and barriers of individual and organisational social capital in terms of whom - the organisation or employee - has the ability to exercise control over the relationship and to experience any accrued benefits. Following this line of reasoning, factors such as personal guanxi, enabling employees in the buyer firm to overcome institutional barriers and instability in the face of regulatory changes and to exchange favours, can be classified into enablers of individual social capital. Whilst other factors, such as multiple points of contact in the supplier firm, which weaken an employee's ability to exercise control over a relationship and mean he/she cannot enjoy the potential benefits for themselves, can be classified as barriers to individual social 
capital. Note that personal guanxi enables all three dimensions of individual social capital and therefore appears in tables V to VII. We recognise that guanxi is a potential double-edged sword and that a dark side can exist, e.g. in the form of collusion. However, we identify the latter, rather than guanxi itself, as the barrier to individual social capital.

[Take in Table IV]

\subsection{Structural Dimension of Social Capital}

Table IV identifies six enablers and seven barriers to organisational structural capital; and two enablers and three barriers to individual structural capital. Example quotes from the interviews can be found in Table V.

\section{[Take in Table V]}

\subsubsection{Organisational Structural Capital and Risk Identification}

Some risk identification strategies are more likely to be employed in collaborative BSRs because they rely, e.g. on detailed and timely information. For example, enablers of organisational structural capital, including corporate communication and regular meetings, illustrate why supplier development activities such as co-location of employees are mainly adopted in collaborative BSRs. HealthCare's Sourcing Leader noted: "We maintain strict standards to monitor and control the raw materials provided by key suppliers. For instance, we house our supplier quality engineers at the suppliers 'factory." Such strategies enable regular information sharing and facilitate buyer-supplier interactions, thereby identifying risks earlier, i.e. at a supplier's site. The shared information can help the buyer anticipate the types, likelihood and consequences of potential risks. For example, Furniture's Supply Chain Manager explained: “We have a regular meeting forum with our key suppliers once or twice a month. Suppliers share their predictions and forecasts about the market, including price fluctuations for raw materials."

When integrated practices such as the above cannot be employed, the buyer may rely on other strategies, e.g. inspecting goods at the buyer's site, to reactively identify risks. As the buyer will be embedded in a wider network, it can also use connections with other firms, e.g. a supplier's competitors, to identify potential SCRs. These practices however are not always effective meaning problems are only identified after the product reaches the market. For example, PetPro's Supplier Quality Assurance (SQA) Manager stated: "We did not realise there was a printing error with dates [i.e. incorrect 'used by' dates] on 
our products until we received complaints from customers."

Barriers to organisational structural capital can expose firms to certain risks. For example, the barrier - a lack of participation - was found to expose a buyer in an adversarial relationship to financial risk. Auto's Brand Manager explained: "Suppliers in a difficult relationship are not willing to share information, especially about their financial performance.", which limited the buyer's options and pushed it to rely on other strategies, e.g. "using a third-party organisation" to identify potential risks. Barriers, such as a supplier's competitors and organisational chaos, were also found to distort information flow and assimilation, impairing the proactiveness and effectiveness of risk identification.

\subsubsection{Individual Structural Capital and Risk Identification}

Like organisational structural capital, individual structural capital enabled by interpersonal communication and guanxi can positively affect risk identification. It can provide an alternative mechanism that enables firms to bypass institutional hurdles and contractual control. Resin's Quality Engineer noted: "If we and the supplier need to deal with a risk incident through contracts, this implies that we do not really have good guanxi [relationship]." Instead, interpersonal communication allows for more flexible conversations and joint problem-solving activities, as explained by Furniture's Sales \& Marketing Manager: "We don't actually rely on the contracts unless there are issues. Even though there are some contractual issues in very rare situations, we try to communicate and solve all kinds of risks and problems." Consequently, these enablers of individual structural capital can help reduce a firm's exposure to certain risks. For example, financial risk may occur in collaborative BSRs but is less likely due to the openness of the guanxi. Alum's Finance Manager stated: "Some suppliers in a good guanxi with us may just call us directly and ask for a favour. They may have a recent problem with capital turnover and wonder if we can support them. We will shorten the accounts payable payment terms or pay cash on delivery."

Barriers to individual structural capital were found to damage risk identification performance. For example, different points of contact in the supplier firm lead to limited information sharing with buyer representatives, making it difficult to develop individual structural capital and effectively identify potential risks. Some barriers, including collusion and limited capacity to process information, illustrate why collaborative BSRs may not always have a positive influence on risk identification. HealthCare's Sourcing 
Leader explained: "One of our collaborative suppliers suddenly shut down their factory ... the supplier provided all of the statements we needed, we cannot blame anyone else because we failed to recognise any problems in the evaluation process." Information was being shared, but the sourcing leader did not have the capacity to process it meaning the risk was not anticipated.

\subsection{Cognitive Dimension of Social Capital}

Table IV identifies four enablers and one barrier to organisational cognitive capital; and two enablers and three barriers to individual cognitive capital. Example quotes can be found in Table VI.

\section{[Take in Table VI]}

\subsubsection{Organisational Cognitive Capital and Risk Identification}

A high level of organisational cognitive capital is supported by an increased tacit understanding, which can help limit unexpected behaviour and misunderstanding. In particular, shared cognition can help reduce the cognitive load and calculative effort involved in risk identification tasks that, to some extent, require a degree of shared understanding (e.g. shared language, culture, and mutual awareness). Consequently, a shared understanding helps the buyer to predict and anticipate potential risks. The data suggests that although risks concerning, for example, quality, price, and logistics exist in collaborative BSRs, buyers in collaborative BSRs may perceived there to be a lower likelihood of them occurring than in adversarial BSRs due in part to the development of joint understanding and shared goals. Resin's Purchasing Manager explained: "Some trustworthy suppliers have been working with us for more than ten years. Risks in price, quality, and delivery exist but are much lower." Collaborative BSRs also tend to feature more of the enabling factors of organisational cognitive capital, e.g. providing training to suppliers. Candy's Site Quality Manager explained: “We provide regular training to our suppliers to help them establish a quality management culture. We also invite them to visit our factories to understand our requirements better."

Data on organisational cognitive capital suggests buyers may employ the same risk identification strategy in different ways according to the BSR type. Many of the buyers interviewed used strategies such as supplier evaluations and auditing across all of their suppliers, but the level of cognitive capital affected how this strategy was implemented and its impact on risk identification performance. PetPro's SQA Manager explained: “For 
assured suppliers in strategic partnerships with us, we evaluate and audit once every three years. It's two years for approved suppliers and one year for in-development suppliers." Enablers such as training and standardisation facilitate the formalisation of shared goals and values creating expected norms of behaviour, resulting in less reliance on regular supplier evaluations and auditing in collaborative than in adversarial BSRs.

The actor taking responsibility for risk identification can shift from buyer to supplier when the two parties are cognitively aligned. For example, suppliers may initiate activities or inform buyers about anticipated risks. PetPro's SQA Manager stated: “Our strategic suppliers do root cause analysis on their own and use tools like fishbone analysis." In these situations, both the buyer and supplier form a shared understanding of the actions required to maintain their business relationship. But barriers that hinder cognitive capital and alignment, including miscommunication, can affect risk identification performance meaning buyers are unable to identify risks before an event occurs. Resin's Quality Engineer recalled: “Because the supplier didn't communicate properly, we didn't realise the risk until it happened." Such a low level of organisational cognitive capital is often found in adversarial BSRs.

\subsubsection{Individual Cognitive Capital and Risk Identification}

Individual cognitive capital is also supported by personal guanxi. Medicine's Senior Purchasing Manager stated: "Of course, good established guanxi is essential in the risk management process as we both [buyer and supplier representative] are willing to build long-term collaboration." These shared cognitions increase the tendency to interact with similar individuals in supplier firms. In collaborative BSRs, individual cognitive capital, enabled by tacit understanding and agreement, can make buyers predict a lower likelihood of certain risks occurring, including quality risk. When these risks however do occur, they can have a severe impact (e.g. on order fulfilment), as explained by HealthCare's Sourcing Leader: "We have to stop our production line because there are quality issues in one part provided by the key supplier $X .$. They either have no issues at all or have huge impacts."

The barriers to individual cognitive capital in the data took the form of collective blindness and a lack of absorptive capacity. Barriers lead to misunderstandings, confusion, and conflicts, which could explain why certain risks such as quality problems are more likely in adversarial BSRs where cognitive capital is typically low. Candy's Lean Manager explained: "Some suppliers might not really understand our requirements or 
why we have such quality requirements. We explain everything to them in detail. After we reach the agreement, problems are quickly resolved." As adversarial BSRs tend to be characterised by low purchasing spend and multi-sourcing, the buyer can also switch to alternative sources of supply, meaning the impact can also be relatively low.

A higher level of individual cognitive capital may not always be beneficial to risk identification. This is because individuals think alike and can become less likely to critically evaluate potential risks, which inhibits risk identification performance. Tyre's Quotation Manager explained: "We often turn a blind eye in most cases, e.g., when the supplier cannot meet the on-time delivery targets. Of course, I know this would bring loss to our company."

\subsection{Relational Dimension of Social Capital}

Table VII identifies three enablers and four barriers to organisational relational capital; and three enablers and three barriers to individual relational capital. Example quotes can be found in Table VII.

[Take in Table VII]

\subsubsection{Organisational Relational Capital and Risk Identification}

Due to a high level of organisational relational capital, shared cooperation norms can lead to a buyer perception that some risk types are less likely in collaborative BSRs than in adversarial BSRs. Indeed, trust in collaborative BSRs can facilitate joint efforts in identifying risk. Meanwhile, the buyer may anticipate that quality risk and opportunism risk appear more likely in adversarial BSRs where trust is lower and suppliers may behave unethically. For example, Alcohol's General Manager stated: "Some suppliers opportunistically plot to do something to us, such as increase the price or mix impurities."

The data on organisational relational capital also suggests different risk identification strategies are employed by buyers in different BSRs. For example, a lack of inter-firm trust in adversarial suppliers leads buyers to adopt certain strategies that they would not employ with collaborative suppliers, e.g. an unannounced inspection. Candy's Lean Manager explained: "For those suppliers in 'transactional' relationships, we sometimes perform unannounced inspections. We go directly to their sites without informing them to get to know their actual performance and identify risks." Auto adopts similar practices, but uses a third-party auditor because the supplier also does not trust the buyer and is not 
willing to disclose its financial performance to them directly. This shows that relational and structural dimensions of social capital can be used together to understand the adoption of risk identification strategies in different BSRs.

Barriers to organisational relational capital, such as exposure to opportunism, can help to understand how opportunism (including intellectual property theft) can occur in collaborative BSRs. HealthCare's Sourcing Leader explained: “As they [the supplier] are involved in the very early design stage, it is very likely that they take away our technology and other confidential information." This is a negative consequence of using early supplier involvement to encourage interaction during the design and planning phase. Further, it demonstrates that a barrier of organisational relational capital (i.e. exposure to opportunism) together with an enabler of organisational structural capital (i.e. corporate communication) can explain why an unexpected opportunism risk may occur in collaborative BSRs. Other barriers, such as a lack of firm-level trust (particularly in adversarial BSRs) and reduced monitoring (specifically in collaborative BSRs), can reduce the proactiveness and effectiveness of risk identification.

\subsubsection{Individual Relational Capital and Risk Identification}

Individual relational capital is shaped by affective commitment based on notions of doing favours, reciprocity and emotional attachment. A high level of individual relational capital enabled by factors such as personal guanxi can lead to a buyer's perception that supply shortage risk appears less likely in collaborative BSRs. Alcohol's General Manager claimed: "We have good guanxi with [Supplier X]. If they know that our order is very urgent, they will unload the moulding tools of other buyers and prioritise our production plans." A higher level of interpersonal trust in relationships, enabling higher individual relational capital, promotes information sharing as part of the formalisation of individual structural capital. Moreover, information sharing reinforces the buyer's ability to foresee and identify possible risks. Resin's Quality Engineer explained: “A supplier in a good guanxi would inform us in advance that they might deliver late, and they would offer us options like 'wait until the full order is ready' or 'deliver part of the order on time'." Thus, such good guanxi enables the buyer to become aware of risks earlier.

Barriers to individual relational capital, such as a lack of motivation to switch supplier because of the fear of potential loss of guanxi, can help to further understand why buyers in collaborative BSRs may become more likely to expose themselves to some risks such as quality risk. Auto's Brand Manager argued: "Even if quality cannot be assured, 
Chinese guanxi will mean we are reluctant to switch to a better supplier for fear of losing current relationships or because we prefer to keep working with friends we have known for many years ... this lowers standards." Other barriers, such as a lack of skills and experience, can make it difficult to employ certain strategies to identify risks, e.g. analysing historical events. Alum's Supply Chain Manager claimed: "Some of our purchasing staff are quite inexperienced. They are not yet capable of establishing business relationships with big suppliers, of communicating with suppliers' top management, or of improving relationships." Together with another barrier, changing purchasing managers, these factors can lead to the loss of guanxi, making it more difficult to identify risks effectively.

\subsection{Cross-Level Effects of Social Capital on Risk Identification}

Social capital in a buyer-supplier dyad is created through a micro-macro process that crosses two distinct levels (i.e. individual and organisational) and generates cross-level effects on risk identification. We now identify the following mechanisms relating to these cross-level effects: (i) convergent effects, whereby the aims and incentives of individuals within the buyer firm are congruent with the aims and incentives of the buyer firm, meaning that even if there is a low level of social capital between organisations, a high level of social capital between individuals can still lead to positive effects for the buyer firm; and, (ii) divergent effects, whereby the aims and incentives of the individuals within the buyer firm are incongruent with the aims and incentives of the buyer firm, meaning that individuals may pursue their own agenda and this may be against the interests of the buyer firm, thus undermining any organisational impact. These two mechanisms are based upon the assumption that the owners of the firms are motivated to pursue organisational interests whereas the individuals that are employed by the firms may or may not always act in the organisational best interests, resulting in convergent and divergent effects on risk identification.

These two mechanisms were found in both types of BSRs, thus creating four quadrants, as shown in Figure 2. Quadrant 1 refers to convergent effects in an adversarial BSR. This happens when an individual in the buyer firm approaches their correspondent in the supplier firm, with whom he/she has interpersonal ties, for a favour in a business exchange. Such positive effects brought about by individual social capital can help firms maintain inter-firm exchanges even if the supplier lacks firm-level trust with the buyer firm, thereby facilitating risk identification activities in adversarial BSRs. This case 
reflects individual social capital complementing organisational social capital in a positive way. Quadrant 2 refers to convergent effects in a collaborative BSR. This can be seen from, for example, how personal guanxi can enable supplier firms to prioritise the production and delivery needs of the buyer over those of other buyers in collaborative BSRs. This scenario is considered the best case for the buyer firm in terms of risk identification as the individual social capital reinforces the positive effects of organisational level social capital. Quadrant 3 refers to divergent effects in an adversarial BSR, where the negative effects of individual social capital, such as caused by collusion, can hurt risk identification in adversarial BSRs. We describe this as the worst case for the buyer firm in terms of risk identification as the buyer appears to lose the initiative and control of the relationship. Finally, Quadrant 4 refers to divergent effects in a collaborative BSR. This indicates that individual social capital is not always reciprocal with organisational social capital, meaning individuals can use their personal ties to pursue their own agenda against organisational interests. The organisation cannot profit from these personal ties and therefore cannot benefit in terms of risk identification.

[Take in Figure 2]

\subsection{Assessement Based on the Multi-Level Social Capital Perspective}

Overall, the findings suggest there are enablers and barriers that influence the formalisation and accumulation of both organisational and individual social capital within BSRs. The level of organisational social capital is a strong indicator of the type of BSR, with implications for SCR and risk identification. A buyer may perceive there to be differing degrees of likelihood and consequence of certain SCRs depending on the BSR type. For example, a buyer may expect quality risk to be very likely in an adversarial BSR (e.g. due to a lack of involvement) and that although it is expected to be less likely to occur in a collaborative BSR, when it does occur the consequences can be severe, e.g. due to the volume of business or degree of integration. In terms of risk identification, buyers may employ different strategies or apply the same strategy in different ways according to the BSR type.

It should also be noted that although the three dimensions of social capital at an organisational and individual level are theoretically different, they can be difficult to separate empirically in relation to risk identification. In fact, there are cross-level effects (i.e. convergent and divergent effects) of organisational and individual social capital on risk identification. Convergent effects appear more likely in collaborative relationships, 
allowing buyers to identify risks earlier than in adversarial BSRs, leading to more proactive and effective risk identification. It was also found that buyers in adversarial BSRs may still be able to effectively identify risks when the convergent effects are in place. Divergent effects that unexpectedly occur in collaborative BSRs can have a negative impact on risk identification, e.g. resulting from collusion and collective blindness.

Social capital theory has utility here but has provided arguably only limited insight into how buyers can identify risks in adversarial BSRs. Given that not all BSRs will be collaborative, it is important that buyers can also identify risks in non-collaborative BSRs. We therefore introduce a second theoretical lens, signalling theory, which allows us to understand how buyers can overcome the information asymmetry that particularly exists in adversarial relationships to identify risks; it can also be used to further examine information sharing in collaborative relationships meaning it complements social capital theory.

\section{Findings: Signalling Theory Perspective}

Signalling theory is best known for its application to labour markets where education (i.e. qualifications) is considered a signal of an employee's (or applicant's) qualities that overcomes information asymmetry in the employer-employee relationship (Spence, 1973). The use of signalling theory has also gained recent attention in the field of operations and SCM (e.g. Stevenson and Busby, 2015; Jayasinghe, 2016). In signalling theory, the two key parties are the sender and receiver of signals. In general, the sender must choose the frequency and method of sending information while the receiver must interpret the signal (Connelly et al., 2011).

The supplier is likely to know much more about supply-side risks to the buyer unless they disclose information. We classify signals into: (i) direct signals, i.e. where a supplier voluntarily and deliberately discloses information about risk to the buyer; and (ii) indirect signals, i.e. where the suppliers' actions or communications contain information about risk but where this disclosure is not the purpose of the action or communication. Our choice of signalling theory, and this classification, partly emerged from the data. For example, Medicine's Purchasing Director explained: “We use strong [direct] and weak [indirect] signals to evaluate if the supplier has any risks in our evaluations and auditing process or during usual communication." 


\subsection{SCR from a Signalling Perspective}

Table VIII provides an overview of signals identified in the data, indicating the signal type (direct vs. indirect), the BSR type where a signal was observed (collaborative $v s$. adversarial), and the implied risk type. An example direct signal is a supplier promising not to increase prices even though market prices are rising, which is a direct indication to the buyer that price risk is low. Meanwhile, a high staff turnover at a supplier may be an indirect signal to the buyer of imminent quality problems due to a loss of expertise. The table identifies thirteen direct and ten indirect signal types from supplier to buyer. Twelve of the direct signals were evident in collaborative BSRs and only two in adversarial BSRs while all ten indirect signals were only identified in adversarial BSRs. Thus, the dominant signal type appears to be related to the form of BSR.

Direct signals about risks are mainly emitted by suppliers in collaborative BSRs, which is logical given that we would expect information to be openly shared here. In contrast, buyers must mainly rely on indirect signals in more adversarial BSRs. For example, a supplier may request early payment on an invoice, and this may be an indirect signal to the buyer of financial problems for the supplier, which is a risk to longer term supply. Medicine's Purchasing Director explained: “Take our packaging supplier as an example, we normally pay them every three to four months. When they call us one or two months early asking if we could pay them, we then need to be very careful. Is this because they have financial problems, their cash flow broke down or any other issues?" The same risk can of course occur in a collaborative BSR, but the supplier may signal more directly and be supported by the buyer avoiding the risk coming to fruition. Alum's Finance Manager stated: "Some suppliers in a good guanxi [relationship] with us may just call us directly and ask for a favour. They may have a recent problem with capital turnover and wonder if we can support them. We will shorten the accounts payable payment terms or pay cash on delivery."

\section{[Take in Table VIII]}

While the above signal-BSR relationship is generally the case, there are exceptions, including where adversarial suppliers send direct signals to buyers. In particular, adversarial suppliers arguably invest in gaining ISO 14001 certification to send a direct signal to buyers about their commitment to the environment and the low level of sustainability risk. In a more collaborative relationship with greater transparency, this commitment would arguably be clear to the buyer regardless of the certification; but in 
more adversarial relationships, ISO 14001 becomes an important signalling device. Of course, it is also important because certification is increasingly becoming an order qualifier for many buyers. Thus, it is not an asset that is specific to a single BSR - it can help the supplier in its transactions with other (new and existing) buyers.

Finally, in our study, we limit our interest to signals carrying information about risk from the supplier (sender) to the buyer (receiver), although there are many other signals in the signalling environment that the buyer may also receive and interpret to identify risks. For example, negative news reports about a supplier, product recalls by competitors that source from the same supplier, and a supplier being unable to fulfil the demand of another customer may all suggest potential supply risks to the buyer. Such signalling is beyond the scope of this paper but warrants more investigation in the future.

\subsection{Risk Identification from a Signalling Perspective}

Connelly et al. (2011) presented a generic timeline (from $\mathrm{t}=0$ to $\mathrm{t}=3$ ) for the signalling process between signaller and receiver where a signal is sent by the signaller and received/interpreted by the receiver (followed by feedback to the signaller). We now contextualise this timeline by making the supplier the sender/signaller and the buyer the receiver; and we expand it to indicate that (i) the supplier may (or may not) have an incentive to misrepresent their actions/intentions and (ii) the buyer may (or may not) have the capacity to interpret the signal correctly, as illustrated in Figure 3. These dimensions are also used in Figure 4, which provides a $2 \times 2$ classification of suitable risk identification strategies observed in the data. Hence it identifies four types of risk identification strategies: interactive, adaptive, passive, and reactive strategies. The $x$ axis refers to the receiver's (buyer's) capacity to interpret the signal correctly (or not) and the $y$ axis refers to the signaller's (supplier's) incentive to misrepresent (or not) their intentions. The latter appears to be related to the type of BSR, i.e. suppliers in adversarial BSRs are more likely to have an incentive to misrepresent than suppliers in collaborative BSRs.

\section{[Take in Figure 3 \& Figure 4]}

In Quadrant 1 of Figure 4, the supplier does not have an incentive to misrepresent and the buyer has the capacity to correctly interpret data or actions. This means the buyer can employ "interactive" strategies to identify risks, such as by evaluating suppliers and inspecting goods at the buyer's site. As the supplier does not have an incentive to 
misrepresent, the buyer can trust them and take them at face value. In Quadrant 2, suppliers do have an incentive to misrepresent their actions but the buyer still has the capacity to correctly interpret data or actions. Therefore, the buyer can employ more "adaptive" strategies, including unannounced inspections, inspecting goods before they leave the supplier's site, and by attempting to translate observed abnormal supplier behaviour into likely risks.

In Quadrant 3, the supplier does not have an incentive to misrepresent but the buyer is unable to interpret correctly. It may therefore need to employ a "passive" strategy where it relies on interpretations by other actors, such as via third-party inspections. There is limited evidence in this quadrant as the buyer is normally able to interpret and translate direct signals sent by a supplier with no incentive to misrepresent into identified risks. Finally, in Quadrant 4, the supplier has an incentive to misrepresent but the buyer is unable to interpret correctly. Here, a buyer may be completely unaware of a potential risk until it materialises or is independently identified by another party, e.g. via customer complaints or feedback from other supply chain actors. We describe these as "reactive" approaches to risk identification.

\subsection{Assessement Based on Social Capital and Signalling Theories}

Signalling theory has been used to complement social capital theory, demonstrating how risks can be identified in collaborative and adversarial BSRs. As discussed above, from a multi-level social capital perspective, buyers can improve risk identification through the development of overall social capital and by converging the aims and incentives of individuals with those of the organisational agenda. Meanwhile, the data suggests that the dominant form of signalling is dependent on the BSR type, i.e. direct signals about risks are mainly emitted by suppliers in collaborative BSRs while more indirect signals are found in adversarial BSRs. Thus, although it is difficult to identify risks through the relationship if it is adversarial, especially when there are divergent effects, buyers can improve risk identification by picking up on the predominantly indirect signals sent by suppliers and by choosing suitable strategies from Figure 4. Indirect signals provide the buyer with an opportunity to 'read between the lines' and translate received signals into risks; and this means buyers can find ways to identify risks even when suppliers do not openly disclose or share information or the buyer cannot benefit from their employees' personal ties. In more collaborative BSRs, direct signals allow the buyer to effectively identify risks by 'reading on the lines'. If divergent effects appear in collaborative 
relationships, risk identification suffers although signals can once again be used to boost risk identification to some degree.

\section{Discussion}

The results from this study provide four key findings and lead to the formulation of five propositions. First, enablers and barriers of the three dimensions of social capital at both an organisational and individual level have been identified. These factors help explain why buyers in different types of BSRs may anticipate SCRs with differing degrees of likelihood and consequence. For example, there appears to be a higher probability but lower impact of quality risk in adversarial BSRs and a lower probability but higher impact in collaborative BSRs. This insight adds, for example, to the debate around whether trust impedes (Cheng et al., 2012; Li et al., 2015; Mishra et al., 2016) or induces opportunism (Chen et al., 2016). Our data suggests this depends on the presence of divergence between organisational and individual social capital, e.g. caused by collective blindness. Although earlier SCR studies (Cheng et al., 2012; Johnson et al., 2013; Hartmann and Herb, 2014) have used social capital theory, they have tended to neglect interactions between the three dimensions, let alone examined interactions across organisational and individual levels. In line with the wider OM literature (Liao and Welsch, 2005; Li et al., 2014), we have found that these interactions add explanatory power and provide a more nuanced understanding of risk identification in different BSRs. For example, different combinations of the dimensions of social capital at both levels can help to explain unexpected risks in collaborative BSRs. For instance, a barrier to individual relational capital (collective blindness) combined with an enabler of organisational relational capital (long relationship history) explains why financial risk exists in collaborative BSRs. Meanwhile, the data suggests buyers may employ different risk identification strategies or apply the same strategy in different ways according to the BSR type. For example, an unannounced inspection is more likely with adversarial than with collaborative suppliers. This leads to our first two propositions:

Proposition 1: A buyer's evaluation of the likelihood and consequences of a given SCR is dependent on the type of BSR.

Proposition 2: Buyers may employ different risk identification strategies or apply the same strategy in different ways according to the type of BSR. 
Second, we find that social capital operates at both an individual and organisational levels of analysis to affect risk identification. This multi-level approach builds on previous studies on social capital at a single level (Lawson et al., 2008; Whipple et al., 2015). Furthermore, enablers for building up organisational social capital were most evident in collaborative BSRs. Enablers of individual social capital however can appear in both types of BSRs, e.g. personal guanxi enables all three dimensions of individual social capital. Hence, our newly identified enablers and barriers to both organisational and individual social capital contribute to the extant BSR literature but particularly to that on SCRM. Our study lends support to previous studies on the dark side of social capital (Villena et al., 2011) and extends this stream by identifying the two distinct cross-level effects, i.e. convergent and divergent effects in different types of BSRs (see Figure 2). In doing so, we refine the existing SCRM literature by suggesting a multi-level social capital perspective, i.e. convergent effects reinforce the positive impact of collaborative BSRs on risk identification, but more importantly, offer those buyers in adversarial BSRs an alternative route to, for example, overcoming institutional hurdles and contractual control (Xin and Pearce, 1996; Shou et al., 2016), thereby improving their risk identification. Moreover, divergent effects can impair the proactiveness and effectiveness of risk identification, not only in collaborative BSRs but also in adversarial BSRs. This leads to the following proposition:

Proposition 3: Social capital resides in BSRs at different levels of analysis (i.e. at an organisational level and an individual level). The impact of organisational social capital on risk identification is contingent upon convergence with individual social capital. Convergence with individual social capital reinforces the positive effects of organisational social capital and divergence induces negative effects.

Third, our signalling analysis suggests that the dominant form of risk signalling may depend on the type of BSR. Few prior studies have referred to risk signalling between actors in the form of early warning indicators (Craighead et al., 2007; Xie et al., 2009; Bode et al., 2014), and none of these contributions explicitly referred to signalling theory. However, our findings are in line with these studies in terms of the importance of early warning indicators for detecting and mitigating risks. We also claim to add to the wider literature on signalling processes (Connelly et al., 2011) by expanding two dimensions from signalling theory within the context of BSRs. It was found (from the perception of 
buyers) that adversarial suppliers are more likely to have an incentive to misrepresent than collaborative suppliers. Hence, more indirect signals were found in adversarial BSRs and more direct signals in collaborative BSRs. Therefore:

Proposition 4: There is a relationship between the signal type received by a buyer from a supplier and the type of BSR. In adversarial BSRs, buyers will mainly receive indirect risk signals from suppliers. In collaborative BSRs, buyers will increasingly receive direct risk signals from suppliers.

Fourth, we find that signalling theory offers a new insight into how buyers can identify risks. This is particularly advantageous in adversarial BSRs where there is information asymmetry. Risk signalling may be a strong and direct signal from one actor to another, alerting the other party to a potential risk event. But it could also be a weaker, indirect signal. For example, it has been suggested that a supplier requesting faster payment may indicate supplier cash flow problems and financial risk (Bode et al., 2014). Such signalling can inform the buyer about potential SCRs. Indeed, previous studies have also stressed how screening early indicators and building warning capabilities are essential to the success of SCRM (Craighead et al., 2007; Kern et al., 2012). Buyers can interpret signals to identify risks in a quick and effective way, including by 'reading between the lines' to translate indirect signals into risks. In more collaborative BSRs, direct signals allow the buyer to effectively identify risks by 'reading on the lines'. This allows risks to be identified in both adversarial and collaborative BSRs, leading to our final proposition:

Proposition 5: Direct and indirect signals can be used to identify the type of risks to which the supply chain is exposed in collaborative and adversarial BSRs.

\section{Conclusions}

This paper started by asking: How does the nature of the BSR affect SCR identification? We collected data from ten Chinese manufacturers and analysed it from a multi-level social capital perspective, complemented by signalling theory. We have been able to extend existing knowledge by identifying the enablers and barriers to social capital at both levels in a developing country context. Furthermore, a buyer may perceive there to be differing degrees of likelihood and consequence of certain SCRs and either employ different risk identification strategies or apply the same strategy in different ways depending on the BSR type. The impact of organisational social capital on risk 
identification is suggested to be contingent upon convergence with individual social capital, i.e. convergence of the aims and incentives between the two levels reinforces the positive impact of organisational social capital and divergence induces negative effects. Social capital theory however failed to offer sufficient explanation concerning how buyers can identify risks in adversarial BSRs. We have shown that it is still possible to identify risks in adversarial relationships by picking up on the indirect risk signals. Further, signalling theory provided a new perspective for classifying suitable risk identification strategies into interactive, adaptive, passive, and reactive approaches (Figure 4).

\subsection{Theoretical Implications}

This study sheds light on how the BSR influences risk identification in a developing country context. It advances social capital as a multi-level theoretical lens and explains how social capital operates at both an individual and organisational level of analysis to affect an organisational-level outcome, i.e. risk identification performance. This represents an important contribution to social capital theory that responds to the research gap identified by Payne et al. (2011). The findings show that understanding individual level social capital is important to understanding organisational level social capital. We identified two different mechanisms relating to the cross-level effects of organisational and individual social capital on risk identification. Finally, we have demonstrated the value of using signalling theory to complement social capital theory, adding explanatory power to risk identification particularly in adversarial BSRs.

\subsection{Managerial Implications}

This study aids managerial understanding of how the types of relationships buyers develop with supply chain partners impact the SCRs they are exposed to; and this awareness may help managers better anticipate and predict potential risks, allowing them to select appropriate strategies to proactively identify risks. Meanwhile, firms should pay attention to individual social capital, evaluate whether the aims of individuals converge with those of the organisation, and determine how best to manage and exploit the relationships between supply chain professionals and individuals in supplier firms. For example, the findings highlight the importance of retaining supply chain professionals that have strong individual ties with suppliers for the good of the overall BSR. Equally, the findings highlight the importance of having multiple contacts or rotating professionals for protecting the organisation from possible negative effects 
when the employed individuals are motivated to act in their own best interests and those interests run contrary to those of the organisation. Thus, firms in both adversarial and collaborative BSRs should encourage their employees to use individual social capital to produce benefits for the organisational purpose; and in doing so, firms can improve risk identification through the development of overall social capital and by fostering convergence between organisational and individual social capital.

In addition, the insights reveal that buyers need to consider how risks can best be identified in the context of a given BSR. It may be, for example, that firms that have adversarial relationships with suppliers need to become competent at reading between the lines to intercept and interpret risk signals. In other words, establishing learning capabilities for the risk signalling process could help firms to better anticipate potential risks. Equally, suppliers themselves need to be aware that buyers may be able to learn about risks not only from their direct actions but also from their indirect actions and consider how this should impact their behaviour.

\subsection{Limitations and Future Research Directions}

This study is based on a qualitative research design. Thus it is acknowledged that the results may lack external validity and the conclusions may be idiosyncratic (Eisenhardt, 1989). Future research could therefore involve a large-scale survey to add generality. Further, only the buyer perspective in the BSR has been captured; hence, future research could extend the work to include suppliers. Although we used the BSR as the smallest unit of analysis to study how supply chain relationships affect risk identification, we have found evidence that other supply chain actors, such as customers, other buyers and competitors also play a role in identifying SCRs, indicating more research could be done in this direction. Similarly, the work could be extended to other stages of the SCRM process. Future research could also explore this topic in other countries where culture may play a different role than in China (guanxi). Our findings show that there are cross-level effects on risk identification between the different levels of social capital. Further research could investigate the impact of other organisational characteristics on the cross-level effects in this context, such as firm size, established routines, and industry sector. Finally, future research could explore how research on SCRM and on supplier relationship management can be more formally integrated. 


\section{References}

Adler, P.S. \& Kwon, S.-W., (2002), "Social Capital: Prospects for a New Concept", The Academy of Management Review, Vol. 27 No. 1, pp. 17-40.

Badurdeen, F., Shuaib, M., Wijekoon, K., Brown, A., Faulkner, W., Amundson, J., Jawahir, I.S., J. Goldsby, T., Iyengar, D. \& Boden, B., (2014), “Quantitative modeling and analysis of supply chain risks using Bayesian theory”, Journal of Manufacturing Technology Management, Vol. 25 No. 5, pp. 631-654.

Barker, G.C., Bayley, C., Cassidy, A., French, S., Hart, A., Malakar, P.K., Maule, J., Petkov, M. \& Shepherd, R., (2010), “Can a Participatory Approach Contribute to Food Chain Risk Analysis?”, Risk Analysis: An International Journal, Vol. 30 No. 5, pp. 766-781.

Barratt, M., Choi, T.Y. \& Li, M., (2011), "Qualitative case studies in operations management: Trends, research outcomes, and future research implications”, Journal of Operations Management, Vol. 29 No. 4, pp. 329-342.

Basole, R.C. \& Bellamy, M.A., (2014), "Visual analysis of supply network risks: Insights from the electronics industry”, Decision Support Systems, Vol. 67 No. 109-120.

Blackhurst, J.V., Scheibe, K.P. \& Johnson, D.J., (2008), “Supplier risk assessment and monitoring for the automotive industry", International Journal of Physical Distribution \& Logistics Management, Vol. 38 No. 2, pp. 143-165.

Bode, C., Hubner, D. \& Wagner, S.M., (2014), "Managing Financially Distressed Suppliers: An Exploratory Study", Journal of Supply Chain Management, Vol. 50 No. 4, pp. 24-43.

Bourdieu, P. \& Wacquant, L.J.D., (1992), An invitation to reflexive sociology, Chicago: University of Chicago Press.

Braunscheidel, M.J. \& Suresh, N.C., (2009), “The organizational antecedents of a firm's supply chain agility for risk mitigation and response”, Journal of Operations Management, Vol. 27 No. 2, pp. 119-140.

Brislin, R.W., (1970), "Back-translation for cross-cultural research", Journal of cross-cultural psychology, Vol. 1 No. 3, pp. 185-216.

Bühler, A., Wallenburg, C.M. \& Wieland, A., (2016), “Accounting for external turbulence of logistics organizations via performance measurement systems”, Supply Chain Management: An International Journal, Vol. 21 No. 6, pp. 694-708.

Burt, R., (2004), "Structural Holes and Good Ideas”, American Journal of Sociology, Vol. 110 No. 2, pp. 349-399.

Camuffo, A., Furlan, A. \& Rettore, E., (2007), "Risk sharing in supplier relations: an agency model for the Italian air-conditioning industry”, Strategic Management Journal, Vol. 28 No. 12, pp. 1257-1266.

Cao, M. \& Zhang, Q.Y., (2011), "Supply chain collaboration: Impact on collaborative advantage and firm performance”, Journal of Operations Management, Vol. 29 No. 3, pp. 163-180.

Carr, A.S. \& Pearson, J.N., (1999), "Strategically managed buyer-supplier relationships and performance outcomes", Journal of Operations Management, Vol. 17 No. 5, pp. 497-519.

Ceryno, P.S., Scavarda, L.F. \& Klingebiel, K., (2015), "Supply chain risk: empirical research in the automotive industry", Journal of Risk Research, Vol. 18 No. 9, pp. 1145-1164.

Chen, C.C., Chen, X.P. \& Huang, S., (2013), “Chinese Guanxi: An Integrative Review and New Directions 
for Future Research", Management and Organization Review, Vol. 9 No. 1, pp. 167-207.

Chen, C.C., Chen, Y.-R. \& Xin, K., (2004), "Guanxi Practices and Trust in Management: A Procedural Justice Perspective", Organization Science, Vol. 15 No. 2, pp. 200-209.

Chen, J., Sohal, A.S. \& Prajogo, D.I., (2016), "Supply risk mitigation: a multi-theoretical perspective", Production Planning \& Control, Vol. 27 No. 10, pp. 853-863.

Cheng, T.C.E., Yip, F.K. \& Yeung, A.C.L., (2012), "Supply risk management via guanxi in the Chinese business context: The buyer's perspective", International Journal of Production Economics, Vol. 139 No. 1, pp. 3-13.

Chopra, S. \& Sodhi, M., (2004), "Managing risk to avoid supply-chain breakdown", MIT Sloan Management Review, Vol. 46 No. 1, pp. 53-61.

Chopra, S. \& Sodhi, M.S., (2014), "Reducing the Risk of Supply Chain Disruptions", MIT Sloan Management Review, Vol. 55 No. 3, pp. 73-80.

Christopher, M. \& Peck, H., (2004), "Building the Resilient Supply Chain”, The International Journal of Logistics Management, Vol. 15 No. 2, pp. 1-14.

Connelly, B., Ireland, R. \& Reutzel, C., (2011), "Signaling Theory: A Review and Assessment”, Journal of Management, Vol. 37 No. 1, pp. 39-67.

Cox, A.W., (2004), Business relationships for competitive advantage: managing alignment and misalignment in buyer and supplier transactions, Basingstoke: Palgrave Macmillan.

Craighead, C.W., Blackhurst, J., Rungtusanatham, M.J. \& Handfield, R.B., (2007), “The severity of supply chain disruptions: Design characteristics and mitigation capabilities”, Decision Sciences, Vol. 38 No. 1, pp. 131-156.

Easterby-Smith, M., (1991), Management research: an introduction, London, Newbury Park: Sage.

Edmondson, A.C. \& Mcmanus, S.E., (2007), "Methodological Fit in Management Field Research", The Academy of Management Review, Vol. 32 No. 4, pp. 1155-1179.

Eisenhardt, K.M., (1989), "Building Theories from Case Study Research”, The Academy of Management Review, Vol. 14 No. 4, pp. 532-550.

Eisenhardt, K.M. \& Graebner, M.E., (2007), “Theory Building from Cases: Opportunities and Challenges”, The Academy of Management Journal, Vol. 50 No. 1, pp. 25-32.

Elleuch, H., Hachicha, W. \& Chabchoub, H., (2014), “A combined approach for supply chain risk management: description and application to a real hospital pharmaceutical case study", Journal of Risk Research, Vol. 17 No. 5, pp. 641-663.

Enyinda, C.I., Mbah, C.H.N. \& Ogbuehi, A., (2010), “An empirical analysis of risk mitigation in the pharmaceutical industry supply chain: A developing-country perspective", Thunderbird International Business Review, Vol. 52 No. 1, pp. 45-54.

Faisal, M.N., Banwet, D.K. \& Shankar, R., (2006), "Supply chain risk mitigation: modeling the enablers", Business Process Management Journal, Vol. 12 No. 4, pp. 535-552.

Faisal, M.N., Banwet, D.K. \& Shankar, R., (2007), "Management of Risk in Supply Chains: SCOR Approach and Analytic Network Process", Supply Chain Forum: An International Journal, Vol. 8 No. 2 , pp. 66-79.

Gaudenzi, B. \& Borghesi, A., (2006), "Managing risks in the supply chain using the AHP method", 
International Journal of Logistics Management, Vol. 17 No. 1, pp. 114-136.

Giannakis, M. \& Louis, M., (2011), “A multi-agent based framework for supply chain risk management”, Journal of Purchasing and Supply Management, Vol. 17 No. 1, pp. 23-31.

Govindan, K. \& Chaudhuri, A., (2016), "Interrelationships of risks faced by third party logistics service providers: A DEMATEL based approach", Transportation Research Part E-Logistics and Transportation Review, Vol. 90 No. 177-195.

Gu, F., Hung, K. \& Tse, D., (2008), "When Does Guanxi Matter? Issues of Capitalization and Its Dark Sides", Journal of Marketing, Vol. 72 No. 4, pp. 12.

Hartmann, E. \& Herb, S., (2014), “Opportunism risk in service triads - a social capital perspective”, International Journal of Physical Distribution \& Logistics Management, Vol. 44 No. 3, pp. 242-256.

Ho, W., Zheng, T., Yildiz, H. \& Talluri, S., (2015), "Supply chain risk management: a literature review”, International Journal of Production Research, Vol. 53 No. 16, pp. 5031-5069.

Inkpen, A.C. \& Tsang, E.W.K., (2005), “Social capital, netwroks, and knowledge transfer”, Academy of Management Review, Vol. 30 No. 1, pp. 146-165.

James, H. \& Faizul, H., (2000), "From arms-length to collaborative relationships in the supply chain: An evolutionary process", International Journal of Physical Distribution \& Logistics Management, Vol. 30 No. 9, pp. 750-764.

Jayasinghe, M., (2016), "The operational and signaling benefits of voluntary labor code adoption: Reconceptualizing the scope of human resource management in emerging economies", Academy of Management Journal, Vol. 59 No. 2, pp. 658.

Jia, F. \& Zsidisin, G.A., (2014), “Supply Relational Risk: What Role Does Guanxi Play?”, Journal of Business Logistics, Vol. 35 No. 3, pp. 259-267.

Johnson, N., Elliott, D. \& Drake, P., (2013), "Exploring the role of social capital in facilitating supply chain resilience”, Supply Chain Management: An International Journal, Vol. 18 No. 3, pp. 324-336.

Jüttner, U., (2005), “Supply chain risk management”, International Journal of Logistics Management, Vol. 16 No. 1, pp. 120-141.

Kayis, B. \& Karningsih, P.D., (2012), “A knowledge-based system tool for assisting manufacturing organizations in identifying supply chain risks", Journal of Manufacturing Technology Management, Vol. 23 No. 7, pp. 834-852.

Kern, D., Moser, R., Hartmann, E. \& Moder, M., (2012), "Supply risk management: model development and empirical analysis", International Journal of Physical Distribution \& Logistics Management, Vol. 42 No. 1 , pp. $60-82$.

Khan, O., Christopher, M. \& Burnes, B., (2008), “The impact of product design on supply chain risk: a case study", International Journal of Physical Distribution \& Logistics Management, Vol. 38 No. 5, pp. 412-432.

Kleindorfer, P.R. \& Saad, G.H., (2005), "Managing disruption risks in supply chains", Production and Operations Management, Vol. 14 No. 1, pp. 53-68.

Krause, D.R., Handfield, R.B. \& Tyler, B.B., (2007), "The relationships between supplier development, commitment, social capital accumulation and performance improvement", Journal of Operations Management, Vol. 25 No. 2, pp. 528-545. 
Kwon, S.-W. \& Adler, P.S., (2014), "Social capital: Maturation of a field of research", Academy of Management Review, Vol. 39 No. 4, pp. 412-422.

Lavastre, O., Gunasekaran, A. \& Spalanzani, A., (2012), "Supply chain risk management in French companies”, Decision Support Systems, Vol. 52 No. 4, pp. 828-838.

Lavastre, O., Gunasekaran, A. \& Spalanzani, A., (2014), "Effect of firm characteristics, supplier relationships and techniques used on Supply Chain Risk Management (SCRM): an empirical investigation on French industrial firms", International Journal of Production Research, Vol. 52 No. 11, pp. 3381-3403.

Lawson, B., Tyler, B.B. \& Cousins, P.D., (2008), “Antecedents and consequences of social capital on buyer performance improvement”, Journal of Operations Management, Vol. 26 No. 3, pp. 446-460.

Leenders, R.T.a.J. \& Gabbay, S.M., (1999), Corporate social capital and liability, Kluwer Academic, Boston.

Li, G., Fan, H., Lee, P.K.C. \& Cheng, T.C.E., (2015), “Joint supply chain risk management: An agency and collaboration perspective”, International Journal of Production Economics, Vol. 164 No. 83-94.

Li, Y., Ye, F. \& Sheu, C., (2014), "Social capital, Information sharing and performance evidence from china", International Journal of Operations and Production Management, Vol. 34 No. 11, pp. 1440-1462.

Liao, J. \& Welsch, H., (2005), "Roles of Social Capital in Venture Creation: Key Dimensions and Research Implications", Journal of Small Business Management, Vol. 43 No. 4, pp. 345-362.

Liker, J.K. \& Choi, T.Y., (2004), “Building deep supplier relationships”, Harvard Business Review, Vol. 82 No. 12, pp. 104.

Lockamy, A. \& Mccormack, K., (2010), “Analysing risks in supply networks to facilitate outsourcing decisions”, International Journal of Production Research, Vol. 48 No. 2, pp. 593-611.

Manuj, I. \& Mentzer, J.T., (2008), “Global supply chain risk management strategies”, International Journal of Physical Distribution \& Logistics Management, Vol. 38 No. 3, pp. 192-223.

Mccutcheon, D.M. \& Meredith, J.R., (1993), “Conducting case study research in operations management”, Journal of Operations Management, Vol. 11 No. 3, pp. 239-256.

Meredith, J., (1998), “Building operations management theory through case and field research”, Journal of Operations Management, Vol. 16 No. 4, pp. 441-454.

Miles, M.B. \& Huberman, A.M., (1994), Qualitative data analysis: an expanded sourcebook, Thousand Oaks: Sage Publications.

Mishra, D., Sharma, R.R.K., Kumar, S. \& Dubey, R., (2016), "Bridging and buffering: Strategies for mitigating supply risk and improving supply chain performance", International Journal of Production Economics, Vol. 180 No. 183-197.

Moran, P., (2005), "Structural vs. relational embeddedness: social capital and managerial performance", Strategic Management Journal, Vol. 26 No. 12, pp. 1129-1151.

Nahapiet, J. \& Ghoshal, S., (1998), "Social capital, intellectual capital, and the organizational advantage", The Academy of Management Review, Vol. 23 No. 2, pp. 242-266.

Narasimhan, R. \& Talluri, S., (2009), "Perspectives on risk management in supply chains", Journal of Operations Management, Vol. 27 No. 2, pp. 114-118. 
Neiger, D., Rotaru, K. \& Churilov, L., (2009), "Supply chain risk identification with value-focused process engineering", Journal of Operations Management, Vol. 27 No. 2, pp. 154-168.

Nishiguchi, T. \& Beaudet, A., (1998), "The Toyota group and the Aisin fire”, Sloan Management Review, Vol. 40 No. 1, pp. 49.

Ojala, M. \& Hallikas, J., (2006), "Investment decision-making in supplier networks: Management of risk", International Journal of Production Economics, Vol. 104 No. 1, pp. 201-213.

Opper, S., Nee, V. \& Holm, H., (2017), "Risk Aversion and Guanxi Activities: A Behavioral Analysis of CEOs in China", Academy of Management Journal, Vol. 60 No. 4, pp. 1504.

Park, S.H. \& Luo, Y., (2001), "Guanxi and organizational dynamics: organizational networking in Chinese firms", Strategic Management Journal, Vol. 22 No. 5, pp. 455-477.

Payne, Tyge, G., Moore, Curt, B., Griffis, Stanley, E., Autry \& Chad, W., (2011), "Multilevel Challenges and Opportunities in Social Capital Research”, Journal of Management, Vol. 37 No. 2, pp. 491-520.

Peck, H., (2005), "Drivers of supply chain vulnerability: an integrated framework", International Journal of Physical Distribution \& Logistics Management, Vol. 35 No. 4, pp. 210-232.

Peng, M.W. \& Luo, Y., (2000), "Managerial Ties and Firm Performance in a Transition Economy: The Nature of a Micro-Macro Link", Academy of Management Journal, Vol. 43 No. 3, pp. 486-501.

Rangel, D.A., De Oliveira, T.K. \& Leite, M.S.A., (2015), "Supply chain risk classification: discussion and proposal”, International Journal of Production Research, Vol. 53 No. 22, pp. 6868-6887.

Riley, J.M., Klein, R., Miller, J. \& Sridharan, V., (2016), "How internal integration, information sharing, and training affect supply chain risk management capabilities", International Journal of Physical Distribution \& Logistics Management, Vol. 46 No. 10, pp. 953-980.

Ritchie, B. \& Brindley, C., (2007), "Supply chain risk management and performance: A guiding framework for future development", International Journal of Operations \& Production Management, Vol. 27 No. 3-4, pp. 303-322.

Robson, C., (2011), Real world research: a resource for users of social research methods in applied settings, Chichester: Wiley.

Roden, S. \& Lawson, B., (2014), "Developing social capital in buyer-supplier relationships: The contingent effect of relationship-specific adaptations", International Journal of Production Economics, Vol. 151 No. 89-99.

Roehrich, J.K., Grosvold, J. \& Hoejmose, S.U., (2014), "Reputational risks and sustainable supply chain management Decision making under bounded rationality", International Journal of Operations \& Production Management, Vol. 34 No. 5, pp. 695-719.

Saunders, M., Lewis, P. \& Thornhill, A., (2016), Research methods for business students.

Schoenherr, T., Rao Tummala, V.M. \& Harrison, T.P., (2008), “Assessing supply chain risks with the analytic hierarchy process: Providing decision support for the offshoring decision by a US manufacturing company", Journal of Purchasing and Supply Management, Vol. 14 No. 2, pp. 100-111.

Scholten, K. \& Schilder, S., (2015), “The role of collaboration in supply chain resilience”, Supply Chain Management: An International Journal, Vol. 20 No. 4, pp. 471-484.

Sharma, S. \& Routroy, S., (2016), "Modeling information risk in supply chain using Bayesian networks", Journal of Enterprise Information Management, Vol. 29 No. 2, pp. 238-254. 
Shou, Z., Zheng, X. \& Zhu, W., (2016), "Contract ineffectiveness in emerging markets: An institutional theory perspective", Journal of Operations Management, Vol. 46 No. 38.

Sorenson, O. \& Rogan, M., (2014), “(When) Do Organizations Have Social Capital?”, Annual Review of Sociology, Vol. 40 No. 261-280.

Spekman, R.E. \& Davis, E.W., (2004), "Risky business: expanding the discussion on risk and the extended enterprise", International Journal of Physical Distribution \& Logistics Management, Vol. 34 No. 5, pp. 414-433.

Spence, M., (1973), “Job Market Signaling”, The Quarterly Journal of Economics, Vol. 87 No. 3, pp. 355-374.

Stevenson, M. \& Busby, J., (2015), “An exploratory analysis of counterfeiting strategies Towards counterfeit-resilient supply chains", International Journal of Operations \& Production Management, Vol. 35 No. 1, pp. 110-144.

Stuart, I., Mccutcheon, D., Handfield, R., Mclachlin, R. \& Samson, D., (2002), "Effective case research in operations management: a process perspective", Journal of Operations Management, Vol. 20 No. 5, pp. 419-433.

Tangpong, C., Michalisin, M.D., Traub, R.D. \& Melcher, A.J., (2015), “A review of buyer-supplier relationship typologies: progress, problems, and future directions", Journal of Business \& Industrial Marketing, Vol. 30 No. 2, pp. 153-170.

Tsai, W. \& Ghoshal, S., (1998), "Social Capital and Value Creation: The Role of Intrafirm Networks", The Academy of Management Journal, Vol. 41 No. 4, pp. 464-476.

Tummala, R. \& Schoenherr, T., (2011), “Assessing and managing risks using the supply chain risk management process (SCRMP)", Supply Chain Management: An International Journal, Vol. 16 No. 6, pp. 474-483.

Villena, V.H., Revilla, E. \& Choi, T.Y., (2011), “The dark side of buyer-supplier relationships: A social capital perspective", Journal of Operations Management, Vol. 29 No. 6, pp. 561-576.

Voss, C., Tsikriktsis, N. \& Frohlich, M., (2002), “Case research in operations management”, International Journal of Operations \& Production Management, Vol. 22 No. 2, pp. 195-219.

Whipple, J.M., Wiedmer, R. \& Boyer, K.K., (2015), “A dyadic investigation of collaborative competence, social capital, and performance in buyer-supplier relationships", Journal of Supply Chain Management, Vol. 51 No. 2, pp. 3-21.

Xie, K.F., Liu, J.M., Peng, H.T., Chen, G. \& Chen, Y., (2009), "Early-warning management of inner logistics risk in SMEs based on label-card system”, Production Planning \& Control, Vol. 20 No. 4, pp. 306-319.

Xin, K.R. \& Pearce, J.L., (1996), “Guanxi: Connections as substitutes for formal institutional support”, Academy of Management Journal, Vol. 39 No. 6, pp. 1641-1658.

Yin, R.K., (2014), Case study research: design and methods, Los Angeles, Calif.: SAGE.

Zsidisin, G.A., (2003), “A grounded definition of supply risk”, Journal of Purchasing and Supply Management, Vol. 9 No. 5, pp. 217-224. 


\section{Contents}

\section{$\underline{\text { List of Tables }}$}

Table I Summary of Research Credibility (adapted from Yin, 2014)

Table II Overview of Case Study Companies

Table III Summary of Supply Chain Risks and Risk Identification Strategies

Table IV Enablers and Barriers to Social Capital at the Organisational and Individual Levels

Table V Enablers and Barriers to Organisational and Individual Structural Capital

Table VI Enablers and Barriers to Organisational and Individual Cognitive Capital

Table VII Enablers and Barriers to Organisational and Individual Relational Capital

Table VIII Signals (Direct and Indirect) and Potential Risks in Adversarial and Collaborative BSRs

\section{List of Figures}

Figure 1 Organisational-Level and Individual-Level Social Capital

Figure 2 Characteristics of Cross-Level Effects of Organisational and Individual Social Capital on Risk Identification in Adversarial and Collaborative BSRs

Figure 3 Signalling Timeline (adapted from Connelly et al., 2011)

Figure 4 Classification of Supply Chain Risk Identification Strategies from a Signalling Perspective

Appendices

Appendix A Interview Questions 
Table I Summary of Research Credibility

\begin{tabular}{|c|c|c|c|c|}
\hline \multirow{2}{*}{ Evaluation Criteria } & \multicolumn{4}{|c|}{ Actions Taken Across Four Phases of the Research } \\
\hline & Research Design & Case Selection & Data Collection & Data Analysis \\
\hline $\begin{array}{l}\text { Construct Validity } \\
\text { (establishes correct } \\
\text { operational measures for the } \\
\text { concepts being studied) }\end{array}$ & $\begin{array}{l}\text { Developed a protocol based } \\
\text { on the extant literature and } \\
\text { a priori theoretical lens. }\end{array}$ & $\mathrm{N} / \mathrm{A}$ & $\begin{array}{l}\text { Piloted the protocol with two } \\
\text { interviewees; multiple sources of } \\
\text { evidence and interviewees. }\end{array}$ & $\begin{array}{l}\text { Informants' validation of } \\
\text { case study report; } \\
\text { obtained feedback from } \\
\text { fellow researchers on } \\
\text { case analysis. }\end{array}$ \\
\hline $\begin{array}{l}\text { Internal Validity } \\
\text { (establishes a causal } \\
\text { relationship, whereby certain } \\
\text { conditions are shown to lead } \\
\text { to other conditions, as } \\
\text { distinguished by spurious } \\
\text { relationships) }\end{array}$ & $\begin{array}{l}\text { Established the evidence } \\
\text { from the literature. }\end{array}$ & $\begin{array}{l}\text { Case included leading } \\
\text { manufacturers from } \\
\text { various industries. }\end{array}$ & $\begin{array}{l}\text { Two interviewees per company; } \\
\text { triangulation supported by } \\
\text { secondary data largely from } \\
\text { websites and corporate reports (or } \\
\text { equivalent). }\end{array}$ & Pattern matching. \\
\hline $\begin{array}{l}\text { External Validity } \\
\text { (establishes a domain in } \\
\text { which the study's findings can } \\
\text { be generalised) }\end{array}$ & $\begin{array}{l}\text { Used replication logic (i.e. } \\
\text { replicate on analytical } \\
\text { rather than statistical } \\
\text { generalisation); multiple } \\
\text { case study design. }\end{array}$ & $\begin{array}{l}\text { Carefully selected } \\
\text { interview participants, } \\
\text { including referrals from } \\
\text { the first to the second } \\
\text { interviewee. }\end{array}$ & & N/A \\
\hline $\begin{array}{l}\text { Reliability } \\
\text { (demonstrates that the } \\
\text { operations of a study can be } \\
\text { repeated with the same } \\
\text { results) }\end{array}$ & $\begin{array}{l}\text { Developed a case study } \\
\text { protocol. }\end{array}$ & $\begin{array}{l}\text { Selected cases based on } \\
\text { theoretical sampling. }\end{array}$ & $\begin{array}{l}\text { Provided the (semi-structured) } \\
\text { questions to all interviewees before } \\
\text { the interview; developed a case } \\
\text { study database (transcripts, } \\
\text { quotations, matrix, codes, memos, } \\
\text { etc.) in NVivo. }\end{array}$ & $\begin{array}{l}\text { Involved another } \\
\text { researcher who did not } \\
\text { collect the data; two } \\
\text { scholars were involved in } \\
\text { the development of } \\
\text { coding. }\end{array}$ \\
\hline
\end{tabular}


Table II Overview of Case Study Companies

\begin{tabular}{|c|c|c|c|c|}
\hline Company & Interviewee Position & Main Products & $\begin{array}{l}\text { No. Employees } \\
\text { (approx.) }\end{array}$ & $\begin{array}{c}\text { Annual Sales } \\
\text { (in Million RMB) }\end{array}$ \\
\hline \multirow{2}{*}{ Candy } & Lean Manager & \multirow{2}{*}{ Candy and other confectionery products } & \multirow{2}{*}{$1,500-2,000$} & \multirow{2}{*}{8,000} \\
\hline & Site Quality Manager & & & \\
\hline \multirow{2}{*}{ PetPro } & Supplier Quality Assurance (SQA) Manager & \multirow{2}{*}{ Pet care products } & \multirow{2}{*}{$1,000-1,500$} & \multirow{2}{*}{1,500} \\
\hline & Senior Lean Manager & & & \\
\hline \multirow{2}{*}{ Alum } & Finance Manager & \multirow{2}{*}{ Aluminium extruded products } & \multirow{2}{*}{$1,000-1,500$} & \multirow{2}{*}{16,000} \\
\hline & Supply Chain Manager & & & \\
\hline \multirow{2}{*}{ Furniture } & Supply Chain Manager & \multirow{2}{*}{ Furniture } & \multirow{2}{*}{$1,000-1,500$} & \multirow{2}{*}{300} \\
\hline & Sales \& Marketing Manager & & & \\
\hline \multirow{2}{*}{ Tyre } & Quotation Manager & \multirow{2}{*}{ Tyres and inner tubes } & \multirow{2}{*}{$7,000-7,500$} & \multirow{2}{*}{3,000} \\
\hline & Purchasing Assistant & & & \\
\hline \multirow{2}{*}{ Resin } & Quality Engineer & \multirow{2}{*}{ Synthetic resin materials } & \multirow{2}{*}{$500-1,000$} & \multirow{2}{*}{1,400} \\
\hline & Purchasing Manager & & & \\
\hline \multirow{2}{*}{ HealthCare } & Sourcing Leader & \multirow{2}{*}{ Medical equipment } & \multirow{2}{*}{$6,000-6,500$} & \multirow{2}{*}{50,000} \\
\hline & Supplier Quality Engineer & & & \\
\hline \multirow{2}{*}{ Alcohol } & General Manager & \multirow{2}{*}{ Alcohol } & \multirow{2}{*}{$100-150$} & \multirow{2}{*}{11} \\
\hline & Purchasing Manager & & & \\
\hline \multirow{2}{*}{ Medicine } & Purchasing Director & \multirow{2}{*}{ Pharmaceutical products } & \multirow{2}{*}{$200-300$} & \multirow{2}{*}{20} \\
\hline & Senior Purchasing Manager & & & \\
\hline Auto & Regional Business Development (RBD) Manager & Automohiles and other $\mathrm{m}$ & $4000-4500$ & 8500 \\
\hline Auto & Brand Manager & Automobiles and other moto & $4,000-4,500$ & 8,500 \\
\hline
\end{tabular}


Table III Summary of Supply Chain Risks and Risk Identification Strategies

\begin{tabular}{|c|c|}
\hline $\begin{array}{l}\text { Supply Chain Risk/ } \\
\text { Identification Strategy }\end{array}$ & Description (Number of Case Companies out of 10) \\
\hline $\begin{array}{l}\text { External to the Supply } \\
\text { Chain (ESC) }\end{array}$ & $\begin{array}{l}\text { ESC1 Natural disasters (3) } \\
\text { ESC2 Political risk (1) } \\
\text { ESC3 Regulation and policy risk (5) } \\
\text { ESC4 Other irregular events (1) }\end{array}$ \\
\hline \multirow[t]{3}{*}{$\begin{array}{l}\text { (External to the } \\
\text { organisation but) } \\
\text { Internal to the Supply } \\
\text { Chain (ISC) }\end{array}$} & $\begin{array}{l}\text { Supply-side } \\
\text { ISC1 Failure to supply required quantity (1) } \\
\text { ISC2 Interrupted supply or supply shortage (3) } \\
\text { ISC } 3 \text { Lack of sufficient capacity (2) } \\
\text { ISC4 Logistics related risks (8) } \\
\text { ISC 5 Packaging risk (2) } \\
\text { ISC6 Price risk (9) } \\
\text { ISC7 Financial instability including bankruptcy (5) } \\
\text { ISC } 8 \text { Technological risk (4) } \\
\text { ISC9 Quality risk (10) } \\
\text { ISC10 Single source of supply (5) } \\
\text { ISC11 Sustainability related risk (6) } \\
\text { ISC12 Contract breach (4) } \\
\text { ISC13 Moral hazard (7) } \\
\text { ISC14 Service risk (2) } \\
\text { ISC15 Lack of supplier involvement (4) } \\
\text { ISC16 Supplier opportunism including intellectual property risk (5) } \\
\text { ISC17 Corruption reporting from other suppliers (1) } \\
\text { ISC18 Product redesign (2) } \\
\text { ISC19 Supplier labour procurement (1) } \\
\text { ISC20 Unavailable or limited local sourcing (3) } \\
\text { ISC21 Wrong choice of supplier (3) } \\
\text { ISC22 Reputation risk (2) }\end{array}$ \\
\hline & $\begin{array}{l}\text { Demand-side } \\
\text { ISC23 Changes in customer requirements (1) } \\
\text { ISC24 Market price fluctuation (3) } \\
\text { ISC25 Seasonal demand (2) } \\
\text { ISC26 Single customer (strong power) (2) }\end{array}$ \\
\hline & $\begin{array}{l}\text { Network-related } \\
\text { ISC } 27 \text { Collusion (2) } \\
\text { ISC } 28 \text { Hoarding and price gouging (2) }\end{array}$ \\
\hline $\begin{array}{c}\text { Internal to the } \\
\text { Organisation (ORG) }\end{array}$ & $\begin{array}{l}\text { ORG1 Behavioural issues (1) } \\
\text { ORG2 Corruption (2) } \\
\text { ORG3 Delayed payments to suppliers (1) } \\
\text { ORG4 Exploiting suppliers (1) } \\
\text { ORG5 Internal coordination problems (1) } \\
\text { ORG6 Power cut (1) } \\
\text { ORG7 Lack of purchasing skills (1) } \\
\text { ORG8 Unbalanced power between departments (1) } \\
\text { ORG9 Unsound purchasing system (1) } \\
\text { ORG10 Production stoppage (1) } \\
\text { ORG11 Lack of risk awareness (1) }\end{array}$ \\
\hline
\end{tabular}




\begin{tabular}{|l|l|}
\hline & RIS1 Observed supplier's abnormal behaviour (9) \\
& RIS2 Unannounced inspections (1) \\
& RIS3 Buyer performs cause-effect analysis (1) \\
& RIS4 Scenario analysis (2) \\
& RIS5 Site inspection at supplier's factory (incl. co-location of employees) (5) \\
& RIS6 SWOT analysis (1) \\
RIS7 Supplier performs cause-effect analysis (1) \\
Risk Identification & RIS8 Supplier evaluation (3) \\
Strategies & RIS9 Historical events (2) \\
& RIS10 Sampling check during supplier selection (1) \\
& RIS11 Inspection of goods at buyer's factory (5) \\
& RIS12 Customer complaints (4) \\
& RIS13 Customs inspection (1) \\
& RIS14 Feedback from downstream supply chain (1) \\
& RIS15 Feedback from other buyers (1) \\
& RIS16 Third-party inspection (3) \\
\hline
\end{tabular}


Table IV Enablers and Barriers to Social Capital at the Organisational and Individual Levels

\begin{tabular}{|c|c|c|c|c|}
\hline & \multicolumn{2}{|c|}{ Organisational Level } & \multicolumn{2}{|r|}{ Individual Level } \\
\hline & Enablers & Barriers & Enablers & Barriers \\
\hline $\begin{array}{l}\text { Structural } \\
\text { Capital }\end{array}$ & $\begin{array}{l}\text { Adoption of IT systems and } \\
\text { software; } \\
\text { Corporate communication; } \\
\text { Local sourcing (including supplier } \\
\text { transfer); } \\
\text { Regular meetings \& forums; } \\
\text { Supplier directory; } \\
\text { Supplier's contacts (or network) }\end{array}$ & $\begin{array}{l}\text { Lack of timely communication; } \\
\text { Lack of top management } \\
\text { support; } \\
\text { Lack of participation; } \\
\text { Long distance; } \\
\text { Lack of visibility; } \\
\text { Supplier's competitors; } \\
\text { Conflicts among departments } \\
\text { (organisation chaos) }\end{array}$ & $\begin{array}{l}\text { Interpersonal } \\
\text { communication; } \\
\text { Personal contacts } \\
\text { (guanxi) }\end{array}$ & $\begin{array}{l}\text { Different points of contact; } \\
\text { Collusion (between an internal actor and } \\
\text { prospective supplier); } \\
\text { Limited capacity to process information }\end{array}$ \\
\hline $\begin{array}{l}\text { Cognitive } \\
\text { Capital }\end{array}$ & $\begin{array}{l}\text { Shared codes and language; } \\
\text { Shared culture; } \\
\text { Standardisation; } \\
\text { Training }\end{array}$ & $\begin{array}{l}\text { Lack of standards; } \\
\text { Miscommunication }\end{array}$ & $\begin{array}{l}\text { Personal contacts } \\
\text { (guanxi); } \\
\text { Tacit understanding or } \\
\text { agreement }\end{array}$ & $\begin{array}{l}\text { Lack of absorptive capacity; } \\
\text { Collective blindness }\end{array}$ \\
\hline $\begin{array}{l}\text { Relational } \\
\text { Capital }\end{array}$ & $\begin{array}{l}\text { Relationship history/length; } \\
\text { Firm-level loyalty; } \\
\text { Firm-level reciprocity }\end{array}$ & $\begin{array}{l}\text { Supplier staff turnover; } \\
\text { Lack of firm-level trust; } \\
\text { Exposure to supplier } \\
\text { opportunism; } \\
\text { Reduced monitoring }\end{array}$ & $\begin{array}{l}\text { Personal contacts } \\
\text { (guanxi); } \\
\text { Commitment; } \\
\text { Goodwill }\end{array}$ & $\begin{array}{l}\text { Change in personnel (purchasing } \\
\text { managers); } \\
\text { (Lack of) motivation to switch supplier; } \\
\text { Lack of purchasing skills or experience }\end{array}$ \\
\hline
\end{tabular}


Table V Enablers and Barriers to Organisational and Individual Structural Capital

$(\mathrm{O}=$ Organisational; $\mathrm{I}$ = Individual $)$

\begin{tabular}{|c|c|c|}
\hline \multicolumn{2}{|c|}{$\begin{array}{c}\text { Structural Capital } \\
\text { (Information sharing; Supplier } \\
\text { development; Supplier evaluation) }\end{array}$} & Illustrative Quotes (Examples) \\
\hline \multirow{8}{*}{ Enablers } & $\begin{array}{l}\text { Adoption of IT systems and } \\
\text { software }(\mathrm{O})\end{array}$ & $\begin{array}{l}\text { HealthCare's Supplier Quality Engineer: "We have an online information system to monitor supplier } \\
\text { performance such as on-time delivery." } \\
\text { Tyre's Quotation Manager: "We use SRM [supplier relationship management] software to manage and } \\
\text { evaluate our suppliers." }\end{array}$ \\
\hline & Corporate communication $(\mathrm{O})$ & $\begin{array}{l}\text { Alcohol's General Manager: "We try our best to solve problems through negotiation and communication. } \\
\text { There is always a way for us to deal with these risks and both of us [buyer and supplier] can make some sort of } \\
\text { concession." }\end{array}$ \\
\hline & $\begin{array}{l}\text { Local sourcing (including } \\
\text { supplier transfer) }(\mathrm{O})\end{array}$ & $\begin{array}{l}\text { HealthCare's Sourcing Leader: "It is much easier to manage local suppliers compared to overseas suppliers. } \\
\text { We can go and visit local suppliers whenever they have problems. Besides, there is no time difference and no } \\
\text { need to have telephone conferences every day." }\end{array}$ \\
\hline & $\begin{array}{l}\text { Regular meetings \& forums } \\
\text { (O) }\end{array}$ & $\begin{array}{l}\text { Furniture's Supply Chain Manager: "We have a regular meeting forum with our key suppliers once or twice a } \\
\text { month. Suppliers share their predictions and forecasts about the market, including price fluctuation for the } \\
\text { raw materials." }\end{array}$ \\
\hline & Supplier directory $(\mathrm{O})$ & $\begin{array}{l}\text { Medicine's Senior Purchasing Manager: "... it is beneficial to establish our supplier database so that we can } \\
\text { track their performance." }\end{array}$ \\
\hline & $\begin{array}{l}\text { Supplier's contacts (or } \\
\text { network) }(\mathrm{O})\end{array}$ & $\begin{array}{l}\text { Furniture's Sales \& Marketing Manager: “...our suppliers will find alternative scarce raw materials for us } \\
\text { through either their suppliers or their peer companies. Their peer companies will help each other in most } \\
\text { cases." }\end{array}$ \\
\hline & $\begin{array}{l}\text { Interpersonal communication } \\
\text { (I) }\end{array}$ & $\begin{array}{l}\text { Furniture's Sales \& Marketing Manager: "We don't actually rely on the contracts unless there are issues. } \\
\text { Even though there are some contractual issues in very rare situations, we try to communicate and solve all } \\
\text { kinds of risks and problems." }\end{array}$ \\
\hline & Personal contacts (guanxi) (I) & $\begin{array}{l}\text { Alum's Finance Manager: "Some suppliers in a good guanxi [relationship] with us may just call us directly } \\
\text { and ask for a favour. They may have a recent problem with capital turnover and wonder if we can support } \\
\text { them. We will shorten the accounts payable payment terms or pay cash on delivery." }\end{array}$ \\
\hline Barriers & $\begin{array}{l}\text { Lack of timely communicate } \\
\text { (O) }\end{array}$ & $\begin{array}{l}\text { Resin's Quality Engineer: "Some suppliers should have informed us earlier before the risk events occurred. } \\
\text { They might not have the awareness to inform us in advance." }\end{array}$ \\
\hline
\end{tabular}




\begin{tabular}{|c|c|}
\hline $\begin{array}{l}\text { Lack of top management } \\
\text { support }(\mathrm{O})\end{array}$ & $\begin{array}{l}\text { Resin's Quality Engineer: "To be honest, no one will remind their line manager that this supplier is risky until } \\
\text { some risks occur, unless this manager is the 'big boss' and fully supports in managing supplier risks." }\end{array}$ \\
\hline Lack of participation $(\mathrm{O})$ & $\begin{array}{l}\text { Auto's Brand Manager: "Our strategic suppliers would take part and cooperate in our audit and evaluation. } \\
\text { They are willing to share information with us. However, other suppliers in a difficult relationship are not } \\
\text { willing to share information, especially about their financial performance. Then we have to investigate using } \\
\text { a [anonymised] third-party organisation to know their financial status." }\end{array}$ \\
\hline Long distance $(\mathrm{O})$ & $\begin{array}{l}\text { Alcohol's General Manager: "We don't have single sourcing in case the single supplier is unable to supply us. } \\
\text { We also have concerns when a supplier is too far from us." }\end{array}$ \\
\hline Lack of visibility $(\mathrm{O})$ & $\begin{array}{l}\text { HealthCare's Sourcing Leader: "Part of the reason why we transfer suppliers to China is to try to reduce the } \\
\text { upstream risks. ... it is very difficult to know what's happening on their sites [when the supplier is outside of } \\
\text { China]." } \\
\text { Auto's Brand Manager: "We are now thinking to integrate and optimise our supplier base as the current } \\
\text { suppliers are fragmented." }\end{array}$ \\
\hline Supplier's competitors $(\mathrm{O})$ & $\begin{array}{l}\text { Resin's Purchasing Manager: "The competition for contracts between suppliers can also cause us problems. } \\
\text { For example, one of our purchasing managers once bought equipment at a lower price from Supplier A [than } \\
\text { had been quoted by Supplier B]. Afterwards, Supplier B [a competitor to Supplier A] reported collusion [i.e. } \\
\text { price fixing] between this purchasing manager and Supplier A to our boss." }\end{array}$ \\
\hline $\begin{array}{l}\text { Conflicts among departments } \\
\text { (organisation chaos) }(\mathrm{O})\end{array}$ & $\begin{array}{l}\text { Alum's Supply Chain Manager: "In the purchasing process, organisation chaos causes a series of purchasing } \\
\text { problems. For example, the finance department was given too much power and authority. As a result, they } \\
\text { made many doubts on items bought in the purchasing department. They have the right to deny purchasing } \\
\text { orders, but by that time the purchased item was already used and we need to pay the suppliers. The finance } \\
\text { department would not process the payments. This is a very serious problem. In a word, it is about the } \\
\text { unbalanced power between the purchasing department and finance department. And of course there is no } \\
\text { visibility. It is not very clear on the ownership and responsibility of each department. This can cause us many } \\
\text { risks." }\end{array}$ \\
\hline Different points of contact (I) & $\begin{array}{l}\text { HealthCare's Sourcing Leader: "Actually, there are different contact windows from this supplier company. } \\
\text { Their sales team are more likely to care about our attitudes when buying their materials. However, when I } \\
\text { need to talk to their production department to add a new requirement on this material, their production } \\
\text { manager does not care and seems like they do not want to talk with me. Who knows how his bad attitude } \\
\text { influences his company." }\end{array}$ \\
\hline $\begin{array}{l}\text { Collusion (between an } \\
\text { internal actor and prospe }\end{array}$ & $\begin{array}{l}\text { Resin's Quality Engineer: "One old supplier has been replaced by our new senior technology manager. This } \\
\text { manager informed the purchasing department that the old supplier is not qualified anymore and a new }\end{array}$ \\
\hline
\end{tabular}




\begin{tabular}{|l|l|} 
supplier) (I) & $\begin{array}{l}\text { supplier with a lower price has been identified. He asked to do business with this supplier. You can see the } \\
\text { power of selecting suppliers is not within the control of the purchasing department." } \\
\text { Medicine's Senior Purchasing Manager: "Suppliers provide inaccurate prices to us in the tender process. } \\
\text { They can be dishonest in order to win the bidding. For example, they try to ascertain the prices quoted by } \\
\text { other suppliers then submit a lower price to bid. Certainly, our staff should not have disclosed the bidding } \\
\text { information. If this supplier wins the bid, the quality of raw materials is a potential threat to us as their price } \\
\text { is unexpectedly lower." }\end{array}$ \\
$\begin{array}{l}\text { HealthCare's Sourcing Leader: "One of our collaborative suppliers suddenly shut down their factory with no } \\
\text { reason. I really doubt how our finance department evaluated that suppliers' financial status several months } \\
\text { ago. How come they didn't find out any warning signs in the supplier's financial statements? The supplier } \\
\text { provided all of the statements we needed, we cannot blame anyone else because we failed to recognise any } \\
\text { problems in the evaluation process." }\end{array}$ \\
\hline information (I)
\end{tabular}


Table VI Enablers and Barriers to Organisational and Individual Cognitive Capital

$(\mathrm{O}=$ Organisational; $\mathrm{I}=$ Individual $)$

\begin{tabular}{|c|c|c|}
\hline \multicolumn{2}{|c|}{$\begin{array}{l}\text { Cognitive Capital } \\
\text { (Shared paradigm; Collective goals) }\end{array}$} & Illustrative Quotes \\
\hline \multirow{6}{*}{ Enablers } & $\begin{array}{l}\text { Shared codes and } \\
\text { language }(\mathrm{O})\end{array}$ & $\begin{array}{l}\text { HealthCare's Sourcing Leader: “... doing business with Chinese [local] suppliers is much easier. You know, there } \\
\text { is no time difference and the same language." }\end{array}$ \\
\hline & Shared culture $(\mathrm{O})$ & $\begin{array}{l}\text { Candy's Lean Manager: "We encourage our suppliers to manage risks according to our requirements. For } \\
\text { example, in order to increase their awareness on quality management, we encourage them to learn our corporate } \\
\text { culture and principles." }\end{array}$ \\
\hline & Standardisation $(\mathrm{O})$ & $\begin{array}{l}\text { Candy's Site Quality Manager: "We have many standard documents for managing our suppliers." } \\
\text { PetPro_1: "We manage our suppliers according to our 'working bible', material quality management standard." }\end{array}$ \\
\hline & Training $(\mathrm{O})$ & $\begin{array}{l}\text { Candy's Site Quality Manager: "We provide regular training to our suppliers to help them establish a quality } \\
\text { management culture. We also invite them to visit our factories to understand our requirements better." }\end{array}$ \\
\hline & $\begin{array}{l}\text { Personal contacts (guanxi) } \\
\text { (I) }\end{array}$ & $\begin{array}{l}\text { Medicine's Senior Purchasing Manager: "Of course, good established guanxi is essential in the risk management } \\
\text { process as we both [buyer and supplier] are willing to build long-term collaboration." }\end{array}$ \\
\hline & $\begin{array}{l}\text { Tacit understanding or } \\
\text { agreement (I) }\end{array}$ & $\begin{array}{l}\text { Candy's Lean Manager: "Some suppliers might not really understand our requirements or why we have such } \\
\text { requirements. We explain everything to then in detail. After we reach the agreement, problems are quickly } \\
\text { resolved." } \\
\text { Medicine's Purchasing Director: "We already achieved the tacit understanding and agreement after working } \\
\text { together for a long time." }\end{array}$ \\
\hline \multirow{4}{*}{ Barriers } & Lack of standards $(\mathrm{O})$ & $\begin{array}{l}\text { HealthCare's Sourcing Leader: "We check if our suppliers have a standard process. If they do have, we will check } \\
\text { if they have any updates and if they are actually following the standard." }\end{array}$ \\
\hline & Miscommunication (O) & $\begin{array}{l}\text { Resin's Quality Engineer: “Because the supplier didn't communicate properly, we didn't realise the risk until it } \\
\text { happened." }\end{array}$ \\
\hline & $\begin{array}{l}\text { Lack of absorptive } \\
\text { capacity (I) }\end{array}$ & $\begin{array}{l}\text { Candy's Lean Manager: "Some suppliers might not really understand our quality requirements or why we have } \\
\text { such requirements." }\end{array}$ \\
\hline & Collective blindness (I) & $\begin{array}{l}\text { Auto's Brand Manager: "If guanxi is not managed properly, it can cause us many problems, especially when both } \\
\text { parties [buyer and supplier] turn a blind eye." } \\
\text { Tyre's Quotation Manager: "One common risk is delivery risk. We [buyer and supplier] know each other well. We } \\
\text { both know we will not go to court even if the supplier does not comply with the delivery agreements in the } \\
\text { contract." }\end{array}$ \\
\hline
\end{tabular}


Table VII Enablers and Barriers to Organisational and Individual Relational Capital $(\mathrm{O}=$ Organisational; $\mathrm{I}=$ Individual $)$

\begin{tabular}{|c|c|c|}
\hline \multicolumn{2}{|c|}{$\begin{array}{c}\text { Relational Capital } \\
\text { (Trust; Friendship; Mutual } \\
\text { obligation; Identification) }\end{array}$} & Illustrative Quotes \\
\hline \multirow{6}{*}{ Enablers } & $\begin{array}{l}\text { Relationship } \\
\text { history/length }(\mathrm{O})\end{array}$ & $\begin{array}{l}\text { Alcohol's General Manager: "After a long time, suppliers become our friends and will keep the same price, even } \\
\text { under seasonal demand." } \\
\text { Resin's Purchasing Manager: "Some trustworthy suppliers have been working with for more than ten years." }\end{array}$ \\
\hline & Firm-level loyalty $(\mathrm{O})$ & $\begin{array}{l}\text { Furniture's Sales \& Marketing Manager: "Many suppliers have limited capabilities. It is useless to force them. } \\
\text { We have requirements, such as that the supplier needs to prioritise to supply and deliver to us when the material } \\
\text { is scarce in the market. If they cannot make it, we can choose not to work with this supplier when we have } \\
\text { sufficient supply. So it is important for us to evaluate whether this supplier is loyal to us." }\end{array}$ \\
\hline & Firm-level reciprocity $(\mathrm{O})$ & $\begin{array}{l}\text { Alcohol's Senior Purchasing Manager: "Some suppliers are in a rapport relationship with us. We are nice to } \\
\text { them in the same way that they are nice to us." }\end{array}$ \\
\hline & $\begin{array}{l}\text { Personal contacts (guanxi) } \\
\text { (I) }\end{array}$ & $\begin{array}{l}\text { Medicine's Senior Purchasing Manager: "Good guanxi with suppliers allows you to do many things, of course, } \\
\text { including risk management." }\end{array}$ \\
\hline & Commitment (I) & $\begin{array}{l}\text { Furniture's Sales \& Marketing Manager: "Some suppliers made commitments to us that they would hold stocks of } \\
\text { raw materials for us. Therefore, they were able to keep the same price when the market price increased." }\end{array}$ \\
\hline & Goodwill (I) & $\begin{array}{l}\text { Alcohol's Senior Purchasing Manager: "We know that they [the supplier] didn't mean to cause quality risks on } \\
\text { purpose." } \\
\text { Medicine's Senior Purchasing Manager: "We both [buyer and supplier] rely on each other with very good } \\
\text { intentions." }\end{array}$ \\
\hline \multirow{3}{*}{ Barriers } & Supplier staff turnover $(\mathrm{O})$ & $\begin{array}{l}\text { Auto's RBD Manager: "High turnover of supplier's staff on the production line would result in quality risk. } \\
\text { Because the new employees may not have experienced skills and knowledge or they don't really understand our } \\
\text { requirements for the parts supplied." }\end{array}$ \\
\hline & $\begin{array}{l}\text { Lack of firm-level trust } \\
\text { (O) }\end{array}$ & $\begin{array}{l}\text { Resin's Purchasing Manager: "Some suppliers with a good reputation have worked with us for a very long time. } \\
\text { We are more like friends now. However, they now seem like they do not want to continue our business. This is not } \\
\text { because they do not trust me anymore. In fact, they don't trust our company and worry that our company is not } \\
\text { able to pay them on time." }\end{array}$ \\
\hline & Exposure to supplier & Auto's Brand Manager: "We have a supplier who makes air-conditioner compressors for us. We have a specific \\
\hline
\end{tabular}




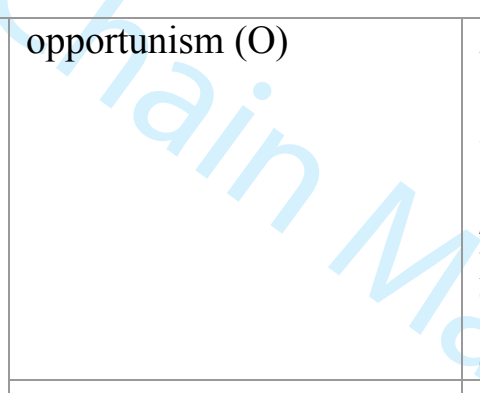

Reduced monitoring (O)

Change in personnel (purchasing managers) (I)

(Lack of) motivation to switch supplier (I)

Lack of purchasing skills or experience (I) requirement on the failure rate. In other words, if the failure rate of this product reaches a certain level, we will lodge a claim to this supplier. If the claim ratio is too high, then we will disqualify and eliminate this supplier because this affects the quality. However, this supplier sent people to different places like service stations and urged them not to report failure rates back to our factory. Rather, they will return the compressor to them. You know, they are worried about the claim ratio. This is the common case in China."

HealthCare's Sourcing Leader: "We do have a potential risk when doing early supplier involvement. As they [the supplier] are involved in the very early design stage, it is very likely that they take away our technology and other confidential information."

Alcohol's Senior Purchasing Manager: "Some suppliers have been working with us for many years. We trust each other and gradually reduce the efforts of monitoring."

Alum's Supply Chain Manager: "To solve lots of problems in the purchasing department, our boss normally would rely on the organisation tools, e.g. change the purchasing managers and the vice president, and so on."

Auto's Brand Manager: "Even if quality cannot be assured, Chinese guanxi will mean we are reluctant to switch to a better supplier for fear of losing current relationships or because we prefer to keep working with friends we have already known for many years."

Alum's Supply Chain Manager: "Some of our purchasing staff are quite inexperienced. They are not yet capable of establishing business relationships with big suppliers, of communicating with suppliers' top management, or of improving relationship etc. Within our company, these young purchasers cannot keep balanced relationship with internal customers like $R \& D$, planning, and sales staff. Many problems and risks are emerging due to ill-managed internal and external relationships." 
Table VIII Signals (Direct and Indirect) and Potential Risks in Adversarial and Collaborative BSRs

\begin{tabular}{|c|c|c|c|c|}
\hline Signal Description & $\begin{array}{c}\text { Adversarial } \\
\text { BSR }\end{array}$ & $\begin{array}{c}\text { Collaborative } \\
\text { BSR }\end{array}$ & Potential Risk(s) & Illustrative Quotes \\
\hline Asking for a favour & & Direct & $\begin{array}{l}\text { (Less) financial } \\
\text { risk }\end{array}$ & $\begin{array}{l}\text { Alum's Finance Manager: "Some suppliers in a good guanxi } \\
\text { [relationship] with us may just call us directly and ask for a favour. They } \\
\text { may have a recent problem with capital turnover and wonder if we can } \\
\text { support them. We will shorten the accounts payable payment terms or pay } \\
\text { cash on delivery." }\end{array}$ \\
\hline $\begin{array}{l}\text { Cash holding or good } \\
\text { cash flow performance } \\
\text { in a good relationship }\end{array}$ & & Direct & (Less) price risk & $\begin{array}{l}\text { Furniture's Sales \& Marketing Manager: "Some suppliers made a } \\
\text { commitment to us that they would hold stocks of raw materials for us. } \\
\text { Therefore, they were able to keep the same price when the market price } \\
\text { increased... so these suppliers (in good guanxi) who are willing to hold } \\
\text { more cash for us are our key suppliers. They can support us in hard } \\
\text { times." }\end{array}$ \\
\hline $\begin{array}{l}\text { Supplier warns the } \\
\text { buyer that they may } \\
\text { not able to supply }\end{array}$ & & Direct & $\begin{array}{l}\text { Supply shortage } \\
\text { risk; Quality risk }\end{array}$ & $\begin{array}{l}\text { Alcohol's Senior Purchasing Manager: "When there is a shortage of raw } \\
\text { materials, we are in a passive position. Suppliers start to demand } \\
\text { favourable requirements for them such as cash on delivery, reduce the } \\
\text { transactions that they sell on credit, or reduce the accounts payable } \\
\text { payment terms and so on. Because they have much more power, they will } \\
\text { implicitly threaten that they cannot supply to you or they will rather lower } \\
\text { the quality." }\end{array}$ \\
\hline $\begin{array}{l}\text { Certification (e.g. ISO } \\
\text { certification) }\end{array}$ & Direct & & $\begin{array}{l}\text { (Less) } \\
\text { sustainability risk; } \\
\text { Quality risk }\end{array}$ & $\begin{array}{l}\text { Resin's Quality Engineer: "For example, things like whether our } \\
\text { suppliers have certifications like ISO and can meet the local requirements } \\
\text { of sustainability or not etc. Why is this important? Because this can cause } \\
\text { us huge problems if they were found not meeting the requirements, they } \\
\text { will be punished - they must stop production for one week or one month } \\
\text { and rectify and reform until it is correct. Consequently, they cannot } \\
\text { delivery to us, which has a great impact on us. In the future, we will pay } \\
\text { more attention to sustainability especially on environmental protection in } \\
\text { our chemical industry." }\end{array}$ \\
\hline A promise not to & & Direct & (Less) price risk & Furniture’s Sales \& Marketing Manager: 'Some suppliers made \\
\hline
\end{tabular}


increase pricing although market prices are rising

\section{Sharing information} about a perceived risk event

Building inventory for the buyer when the raw material price is low

Finding alternative
sources of supply for the buyer

Maintaining the same price under seasonal demand

\begin{tabular}{|c|c|c|}
\hline $\begin{array}{l}\text { Supplier offering } \\
\text { continuous } \\
\text { improvement } \\
\text { suggestions }\end{array}$ & Direct & (Less) quality risk \\
\hline $\begin{array}{l}\text { Supplier prioritising } \\
\text { delivery or service for } \\
\text { the buyer }\end{array}$ & Direct & $\begin{array}{l}\text { (Less) supply } \\
\text { shortage risk }\end{array}$ \\
\hline $\begin{array}{l}\text { Supplier prioritising } \\
\text { production plans for }\end{array}$ & Direct & $\begin{array}{l}\text { (Less) supply } \\
\text { shortage risk }\end{array}$ \\
\hline
\end{tabular}

commitments to us that they would hold stocks of raw materials for us. Therefore, they were able to keep the same price when the market price increased.'

Resin's Quality Engineer: “The supplier in good guanxi would inform us in advance that they might deliver later, and they would offer us options like 'wait until the full order is ready' or 'deliver part of the order on time."."

Furniture's Sales \& Marketing Manager: "Some suppliers hold wood inventory for us when the market price is very low. We would also pay them in advance and support them to hold inventory for us. As a result, we can buy the materials at a lower price and reduce our costs."

Furniture's Sales \& Marketing Manager: "There are some situations where suppliers will help us to protect against risks. For example, our suppliers will find alternative scarce raw materials for us through either their suppliers or their peer companies. Their peer companies will help each other in most cases."

Alcohol's General Manager: "After a long time, suppliers become our friends and will keep the same price under seasonal demand."

Candy's Lean Manager: "Suppliers will also offer improvement suggestions to us. For example, our packaging supplier A know we have issues with batch management at distributors. This supplier offered us a very good suggestion that we can use tapes with different colours to represent different months of $B B D$ [best before date] so that the distributors can refer to the colour to achieve FIFO [first-in-first-out] in their inventory management. This would help reduce the rate of aged products."

Furniture's Sales \& Marketing Manager: "Some of our suppliers with good guanxi would prioritise to supply and deliver to us when the material is scarce in the market."

Alcohol's General Manager: "We have good guanxi with [Supplier X]. If they know that our order is very urgent, they will unload the moulding 


\begin{tabular}{|c|c|c|c|c|}
\hline the buyer & & & & tools of other buyers and prioritise our production plans." \\
\hline $\begin{array}{l}\text { Service becomes } \\
\text { worse }\end{array}$ & Direct & Direct & Service risk & $\begin{array}{l}\text { Auto's Brand Manager: "Suppliers' behaviours can help us to identify } \\
\text { risks. Some indicators like service becoming worse would indicate } \\
\text { service risk to us." }\end{array}$ \\
\hline $\begin{array}{l}\text { Decreasing or } \\
\text { discounting prices } \\
\text { when the market price } \\
\text { is flat }\end{array}$ & Indirect & & Quality risk & $\begin{array}{l}\text { Alcohol's Senior Purchasing Manager: "One supplier unexpectedly told } \\
\text { us that they could lower the price for us. We supposed that there were } \\
\text { quality issues in that batch and this is why they wanted to sell it at a } \\
\text { cheaper price" }\end{array}$ \\
\hline $\begin{array}{l}\text { Requesting early } \\
\text { payment }\end{array}$ & Indirect & & Financial risk & $\begin{array}{l}\text { Alum's Finance Manager: "Some suppliers said that they can offer us } \\
\text { more discounts if we can pay them earlier. This might be that they have } \\
\text { issues in capital turnover or they have less cash available, indicating a } \\
\text { potential bankruptcy risk to us." } \\
\text { Medicine's Purchasing Director: "Take our packaging supplier as an } \\
\text { example, we normally pay them every three to four months. When they } \\
\text { call us one or two months early asking if we could pay them, we then need } \\
\text { to be very careful. Is this because they have financial problems, their cash } \\
\text { flow broke down or any other issues? This is concerning whether they can } \\
\text { sustain their business. We would consider that it is time we initiated our } \\
\text { back up plan." }\end{array}$ \\
\hline $\begin{array}{l}\text { Increasing the price } \\
\text { when the market price } \\
\text { is flat }\end{array}$ & Indirect & & $\begin{array}{l}\text { Price risk; } \\
\text { Contract risk; } \\
\text { Opportunism risk }\end{array}$ & $\begin{array}{l}\text { Alcohol's Senior Purchasing Manager: "If the supplier initially breaches } \\
\text { the contract then they will be punished. But the sudden hike in price by } \\
\text { this supplier might imply that he wanted you to induce or force you to } \\
\text { initiate the action to discontinue the contract. Then he would not be } \\
\text { punished... This is sensible, right? When another customer offered them a } \\
\text { higher price, this is profitable for them to opportunistically breach the } \\
\text { contract. In the situations where the penalty is very high, he would try all } \\
\text { means to force you to initiate the action." }\end{array}$ \\
\hline $\begin{array}{l}\text { Market price increases } \\
\text { but no request is made } \\
\text { to increase the price }\end{array}$ & Indirect & & Quality risk & $\begin{array}{l}\text { Auto's RBD Manager: "Suppliers are also facing the rise in raw material } \\
\text { prices, indicating less profit margins for them. They fear that they would } \\
\text { lose some current customers if they request to increase the price of raw } \\
\text { materials. Instead, they would rather figure out how they reduce the costs } \\
\text { of product structure, equipment, technology etc. and sacrifice higher }\end{array}$ \\
\hline
\end{tabular}




\begin{tabular}{|c|c|c|c|}
\hline+1 & & & levels of quality standard. This would be increased quality risk for us." \\
\hline $\begin{array}{l}\text { Requesting to change } \\
\text { supply to another } \\
\text { company }\end{array}$ & Indirect & $\begin{array}{l}\text { Contract risk; } \\
\text { Service risk }\end{array}$ & $\begin{array}{l}\text { Alum's Supply Chain Manager: "One type of material we need is the } \\
\text { cutting tool. There are various types of this product in the market. We } \\
\text { choose one supplier of relatively low priced good quality tools ... value } \\
\text { for money. We want to purchase from this supplier. However, the supplier } \\
\text { does not allow us to place orders with them. They request us to purchase } \\
\text { from one of their dealers, which is a very small firm. There are no } \\
\text { established business processes and systems. Although the quality of the } \\
\text { cutting tools is very good, it performed badly at response speed and } \\
\text { follow-up service." }\end{array}$ \\
\hline $\begin{array}{l}\text { Requesting to pay a } \\
\text { sub-company }\end{array}$ & Indirect & Contract risk & $\begin{array}{l}\text { Alum's Supply Chain Manager: "Some suppliers request to pay a } \\
\text { third-party company after you purchased from their companies. This is a } \\
\text { very complicated case, remaining a risk to us." }\end{array}$ \\
\hline $\begin{array}{l}\text { Shareholder structure } \\
\text { or ownership becomes } \\
\text { more concentrated }\end{array}$ & Indirect & $\begin{array}{l}\text { Financial risk; } \\
\text { Supply } \\
\text { interruption risk }\end{array}$ & $\begin{array}{l}\text { Auto's Brand Manager: "Everything looks fine on the financial statements } \\
\text { of ... [at new supplier]. Later, we found this supplier was suffering } \\
\text { financial distress as their venture capital partner [the majority } \\
\text { shareholder] went bankrupt. Therefore, they cannot supply to us } \\
\text { anymore." }\end{array}$ \\
\hline $\begin{array}{l}\text { A request to shorten } \\
\text { accounts payable } \\
\text { payment terms }\end{array}$ & Indirect & Financial risk & $\begin{array}{l}\text { Alum's Finance Manager: "Some suppliers request us to shorten the } \\
\text { accounts payable payment terms. They probably have difficulties in their } \\
\text { cash flow." }\end{array}$ \\
\hline $\begin{array}{l}\text { Staff change or } \\
\text { turnover }\end{array}$ & Indirect & Quality risk & $\begin{array}{l}\text { HealthCare's Supplier Quality Engineer: "The job-hopping rate and staff } \\
\text { turnover rate are quite high in some of our domestic suppliers. There are } \\
\text { lots of issues on work handover particularly when staff suddenly leave } \\
\text { without a clear handover to the new employee." } \\
\text { Auto's RBD Manager: "A high turnover of a supplier's staff on the } \\
\text { production line would result in quality risk... because the new employees } \\
\text { may not have experienced skills and knowledge or they don't really } \\
\text { understand our requirements of the parts." }\end{array}$ \\
\hline $\begin{array}{l}\text { Strategy change, e.g. } \\
\text { investing in other } \\
\text { markets }\end{array}$ & Indirect & $\begin{array}{l}\text { Supply shortage } \\
\text { risk }\end{array}$ & $\begin{array}{l}\text { Auto's Brand Manager: "One supplier was gradually changing their } \\
\text { investment strategy and shrinking the current production for the part they } \\
\text { supply to us." }\end{array}$ \\
\hline
\end{tabular}


Figure 1 Organisational-Level and Individual-Level Social Capital

Convergent Effects

Divergent Effects

\section{Figure 2 Characteristics of Cross-Level Effects of Organisational and Individual Social}

Capital on Risk Identification in Adversarial and Collaborative BSRs

\begin{tabular}{|c|c|c|}
\hline \multirow[b]{2}{*}{ Convergent Effects } & $\begin{array}{c}\text { Quadrant 1: Convergent Effects in an } \\
\text { Adversarial BSR }\end{array}$ & $\begin{array}{c}\text { Quadrant 2: Convergent Effects in a } \\
\text { Collaborative BSR (Best Case Scenario for } \\
\text { Risk Identification) }\end{array}$ \\
\hline & $\begin{array}{l}\text { Description: Assets and resources made } \\
\text { available through individual social capital } \\
\text { that an individual can use to produce } \\
\text { benefits for organisational purposes in an } \\
\text { adversarial BSR, indicating why the buyer } \\
\text { is able to effectively identify risks in an } \\
\text { adversarial relationship. }\end{array}$ & $\begin{array}{l}\text { Description: Assets and resources made } \\
\text { available through individual social capital } \\
\text { that an individual can use to produce } \\
\text { benefits for organisational purposes in a } \\
\text { collaborative BSR, indicating why the } \\
\text { buyer can effectively identify risks in a } \\
\text { collaborative relationship. }\end{array}$ \\
\hline & $\begin{array}{c}\text { Quadrant 3: Divergent Effects in an } \\
\text { Adversarial BSR (Worst Case Scenario for } \\
\text { Risk Identification) }\end{array}$ & $\begin{array}{c}\text { Quadrant 4: Divergent Effects in a } \\
\text { Collaborative BSR }\end{array}$ \\
\hline Divergent Effects & $\begin{array}{l}\text { Description: Assets and resources made } \\
\text { available through individual social capital } \\
\text { that an individual can use to pursue their } \\
\text { own gain against organisational interests in } \\
\text { an adversarial BSR, indicating why the } \\
\text { buyer cannot effectively identify risks in an } \\
\text { adversarial relationship. }\end{array}$ & $\begin{array}{l}\text { Description: Assets and resources made } \\
\text { available through individual social capital } \\
\text { that an individual can use to pursue their } \\
\text { own gain against organisational interests in } \\
\text { a collaborative BSR, indicating why the } \\
\text { buyer cannot always effectively identify } \\
\text { risks in a collaborative relationship. }\end{array}$ \\
\hline
\end{tabular}


Figure 4 Classification of Supply Chain Risk Identification Strategies from a Signalling

\section{Perspective}

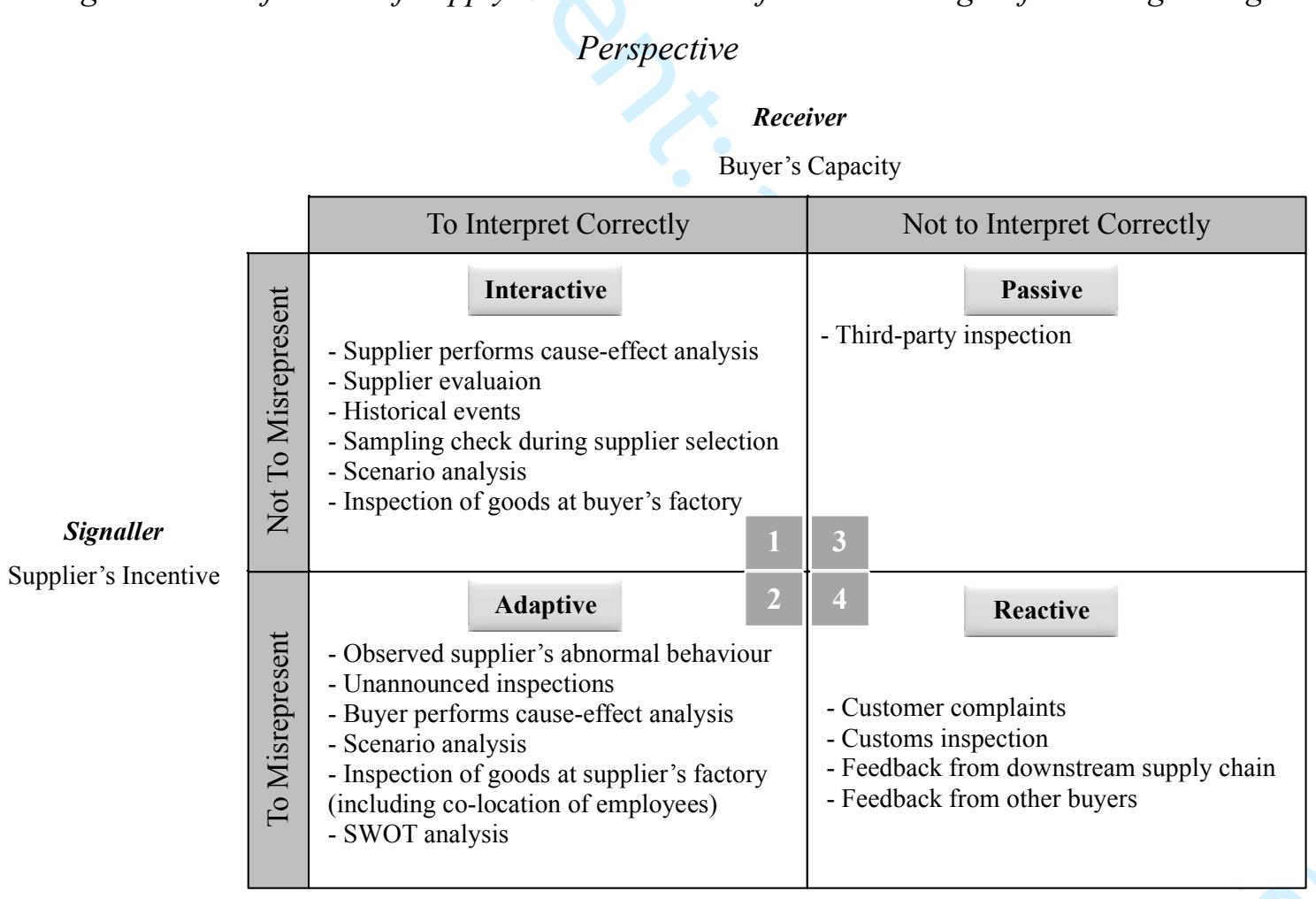




\section{Appendix A Interview Questions}

\section{General Background}

1.1 Background on organisation, position, job title, and responsibilities.

2.2 What is your understanding of buyer-supplier relationships, supply chain risk, and risk identification in particular?

\section{SCRs and Risk Identification Strategies}

2.1 Which of the following supply chain risks are most relevant to your company?

- Inability to meet quality requirements

- Inability to adapt to required product design or technological changes

- $\quad$ Failures to make delivery requirements

- Cannot provide competitive pricing (including sudden hike in costs)

- $\quad$ Supplier opportunism (including intellectual property risk)

- Contractual agreements

- $\quad$ Single source of supply

- $\quad$ Selection of wrong partner

- $\quad$ Financial instability, including bankruptcy

- $\quad$ Lack of supplier involvement

- Sustainability related problems

Are there any other supply chain risks (not listed) that are relevant to your company?

2.2 What strategies has your company used to identify risks, and how effective have these been?

\section{Types of BSR, SCR, and Risk Identification}

3.1 What are the different types (characteristics) of working relationships with your suppliers? How critical is a supplier in each type to your overall business?

3.2 How do the types of relationships you have with suppliers affect supply chain risk?

3.3 How has working with your suppliers (with examples from different types of relationships) influenced risk identification?

3.4 How would you evaluate your working relationships with your suppliers regarding supply chain risks and supply chain risk management?

\section{Final Comments}

Are there any further comments that you think are relevant to this research that either affect the company now or may do in the future? 